\title{
Potential Welfare Loss from Using Imperfect Environmental Taxes ${ }^{\dagger}$
}

\author{
Inkee Hong*
}

ABSTRACT : In environmental policy areas, a greater use of economic instruments (EIs) has recently been observed in many countries. However, EIs are heterogeneous policy tools. The textbook case of a Pigouvian tax is far from widely used, mainly due to the information requirements and other structural and institutional constraints. The successful implementation of Els might heavily depend on pre-existing structural and institutional conditions. Moreover, these institutional conditions are particularly unfavorable in developing countries. Using a simple analytical general equilibrium model, this paper examines how these constraints affect the welfare gain from the introduction of environmental taxes in developing countries. First, this paper solves for the second-best optimal Pigouvian tax and output tax in the presence of a distortionary tax on market use of labor. The result confirms that an environmental output tax achieves a socially-efficient level of emissions in the least-cost manner only if the nature of the linkage between the tax base and the environmental damage is fixed. Second, incorporating structural and institutional constraints into the model through a set of parameter values from China and the US, this paper calculates the net welfare effects of either using the ideal Pigouvian tax or instead using an output tax. The numerical simulation results show that the net welfare gain from the use of an ideal Pigouvian tax could be more than six times larger than that of an output tax in developing countries. On the other hand, the welfare gain is only 50 percent in developed countries. This means that the potential welfare disadvantage from using output taxes instead emissions tax for environmental purposes could be much greater in the case of developing countries.

Keywords : Emissions Tax, Output Tax, Environmental Taxation, Optimal Taxation, Environmental Policies, Developing Countries

JEL 분류: H21, H23, Q56

Received: December 7, 2014. Revised: March 17, 2015. Accepted: March 19, 2015.

${ }^{\dagger}$ This research was supported (in part) by the Daegu University Research Grant, 2012.

*Assistant Professor, Room \#2207, Dept. of Economics, Daegu University, 201 Daegudae-ro, Gyeongsan-si, Gyeongsangbuk-do, 712-714, Republic of Korea(e-mail: ihong@daegu.ac.kr) 


\title{
불완전한 환경세 사용에 따른 잠재적 후생 손실
}

\author{
홍인기*
}

요 약 : 지난 30년간 환경세나 배출권과 같은 경제적 정책도구들이 환경정책의 영역에서 꾸준 히 각광을 받아왔다. 경제적 환경정책도구들은 저마다 특성이 다르고, 각국 정책당국이 직면한 환경문제의 구조적 제도적 배경이 상이하기 때문에, 교과서적인 의미에서의 피구세(배출세)와 같은 정책도구는 널리 사용되지 못하는 상황이다. 오히려 산출물이나 소비 등에 부과하는 환경 관련 조세를 부과함으로써 피구세 사용에 수반되는 한계와 어려움을 회피하려는 경향이 강하 다. 즉, 피구세(배출세)를 사용하지 못함으로써 이미 상당한 후생손실을 감내할 수밖에 없는 것 이다. 특히 개발도상국들에서는 구조적 제도적 제약들이 선진국에 비해서 더 많고 크기 때문에, 제대로 된 피구세(배출세)를 사용하지 못함에 따라 입는 후생손실이 휠씬 커질 수 있다. 본 논 문에서는 이 점을 보여주기 위해서, 이론적인 일반균형모형을 통해 노동에 대한 과세가 존재하 는 차선의 상황에서, 피구세 및 산출세 수준을 최선과 차선의 경우에 계산하고, 각종 구조적 제 도적 제약을 모형 내의 파라미터로 표현한 사회후생 수식을 통해 도출해낸다. 그리고 피구세에 대한 불완전하지만 현실적인 대안으로 산출세를 이용하여 환경문제를 해결하려 하는 경우, 후 생증진의 차이가 얼마나 벌어지는지 살펴본다. 또한 미국과 중국의 예를 들어, 환경 차원에서 불완전한 산출세를 사용함으로써 겪는 후생손실이 개도국의 경우 산업국가에 비해서 무려 6 배 나 벌어질 수 있음을 시뮬레이션을 통해 보여준다.

주제어 : 배출세, 피구세, 산출물세, 환경세, 최적조세, 환경정책, 개발도상국

접수일(2014년 12월 7일), 수정일(2015년 3월 17일), 게재확정일(2015년 3월 19일) ${ }^{\dagger}$ 이 논문은 2012학년도 대구대학교 학술연구비지원에 의한 논문임을 밝힙니다.

" 대구대학교 경제학과 조교수(e-mail: ihong@daegu.ac.kr) 


\section{Introduction}

Many developed countries have implemented various policy measures to protect and improve the quality of their environment. Recent studies (OECD, 1995; 2001; 2006; 2012; Stavins, 2003) have identified major advantages to a greater use of 'economic instruments' (EIs) such as taxes or charges and tradable permits in environmental policy, compared to 'command and control' (CAC) approaches. However, EIs are heterogeneous policy tools. The textbook case of a Pigouvian tax is far from widely used, mainly due to the information requirements and other institutional constraints (McMorran and Nellor, 1994). The successful implementation of EIs might heavily depend on pre-existing institutional conditions (Russell and Powell, 1996; Smith, 1997).

These institutional conditions are particularly unfavorable in developing countries. Existing regulations, usually fashioned after those in developed countries, have often proven unenforceable and impractical. The efforts required to cope with the design of these policies and institutional changes for launching EIs are additional burdens on those developing nations (Panayotou, 1991; Serôa da Motta, et al. 1999; Bell and Russell, 2002, Speck and Gee, 2011, OECD, 2012). Developing countries also have other structural characteristics different from those of developed countries. They often use more polluting fuels such as coal and unleaded gasoline, engage in more-harmful and less-efficient consumption and production activities such as slash-and-burn farming in Brazil and Indonesia (Varma, 2003), and drive more polluting vehicles per mile traveled such as small scooters in many South Asian countries. Finally, they tend to have agricultural that are large and often under-taxed, polluting industries that account for a large proportion of total output, and high marginal environmental damages per unit of output.

This paper examines how these constraints affect the possible welfare gain from the introduction of environmental taxes in developing countries. It uses a simple analytical general equilibrium model with three sectors: one taxable clean manufacturing sector, 
one polluting manufacturing sector, and one non-taxable clean sector that represents subsistence farming and/or small non-market production activities.

First, this paper theoretically shows that an ideal Pigouvian tax provides larger welfare gain than an output tax. Leaving aside problems of monitoring or enforcement, a Pigouvian tax is an ideal instrument to internalize an environmental externality because it reduces consumption of the output as well as use of the dirty input. Using the log-linearization technique, this paper solves for the second-best optimal Pigouvian tax and output tax in the presence of a distortionary tax on market use of labor (or equivalently, a pre-existing consumption tax on all market goods).

Second, the model allows structural constraints to be incorporated and quantified through a set of parameter values rather than relies on anecdotal evidence that developing countries have experienced. The paper uses data for China, which is believed to share many characteristics commonly observed in developing countries in a broad sense. Using the data for China, I calculate the net welfare effects of either using the ideal Pigouvian tax instead using an output tax. The numerical simulation results show that the net welfare gain from the use of a Pigouvian tax could be more than six times larger than that of an output tax. On the other hand, the welfare gain from using a Pigouvian tax is only 50 percent larger than that of an output tax in developed countries. Therefore, the potential welfare loss from using output taxes for environmental purposes appears to be greater in developing countries. This potential welfare disadvantage implies that developing countries' efforts in various structural reforms have important effects on the welfare outcomes of their environmental policies.

Section II briefly overviews past experiences with EIs as well as the previous literature. In Section III, I present the model and derive the optimal tax rates and net welfare expressions for both the emissions tax and output tax. Section IV discusses the implications of these analytical results, while Section V presents simulation results. Section VI concludes. 


\section{Past Experiences with Economic Instruments in Developing Countries}

The traditional and most direct approach to environmental management is to impose technology restrictions and guidelines, enforced using fines and fees. But this CAC method can be difficult and expensive to implement, monitor, and enforce. In the economic literature, the CAC approach has been explored on grounds of both static and dynamic inefficiency, because it asks for the same level of compliance by all polluters despite differences in marginal abatement costs. Furthermore, it does not provide any incentives to polluters for technical improvement to reduce pollution in the future (Baumol and Oates, 1988; Cropper and Oates, 1992).

EIs include both taxes and permit systems, but the model in this paper is based on perfect certainty and thus does not really distinguish between them. Since taxes and permits are equivalent, I refer only to Pigouvian taxes (fees or charges) and environmental output taxes. 1) A Pigouvian tax (or emissions tax) is a specific tax per unit of emissions. The optimal rate of tax is equal to the pollutant's social marginal environmental damage (MED) at the socially-efficient level of emissions (Pigou, 1932). In theory, Pigouvian taxes reduce pollution in the least-cost manner: they encourage polluters to determine the combination of lower output, substitution among inputs, and investment in new technology that reduces emissions at least cost.

On the other hand, taxes on output or purchased inputs might be used for environmental purposes, though they have traditionally been used mainly for revenue purposes. ${ }^{2}$ ) In many cases, they are intended to encourage pollution abatement by taxing outputs or

1) Some studies (OECD, 1999b; Smith, 1997) divide environmental tax instruments into charges (or fees) and taxes based on whether they are requited or not. However, in this paper, I will use all these terms interchangeably.

2) I will use 'Pigouvian tax' for a tax per unit of emissions and "output tax" for a tax on output of the polluting industry. Therefore, by my definition, the most important characteristic in determining if any particular tax (or charge) belongs to the Pigouvian tax category depends on whether it directly hits the emissions themselves. If not, I will call it an output tax. 
inputs whose use is linked to environmental damage, rather than taxing emissions directly. Unlike a Pigouvian tax, however, an output (or input) tax achieves a sociallyefficient level of emissions in the least-cost manner only if the nature of the linkage between the tax base and the environmental damage is fixed. Without fixed linkage to pollution, they usually deliver only the output effect (Fullerton, et al., 2001). In other words, they do not provide incentives to abate emissions per unit of output; they only reduce consumption of goods and services produced using emissions. ${ }^{3)}$ Furthermore, they may affect other non-targeted activities (Eskeland and Jimenez, 1992).

Why are environmental output (or input) taxes so popular then? First of all, environmental output taxes are relatively easier to administer than ideal Pigouvian taxes. For design and implementation of a perfect Pigouvian tax, the environmental authorities would have to monitor the sources of pollutants continuously, enforce the potential polluters to comply, and decide the optimal rate of tax for each polluter. These administrative activities are by no means easy tasks, even in developed countries. ${ }^{4)}$ The situations in many developing countries are worse: their institutional weaknesses such as under-funding and inexperience tend even further to limit the effective implementation of Pigouvian taxes.5) Furthermore, it is often difficult to introduce new environmental taxes. In comparison, output taxes are relatively easy to implement.6) Many existing taxes are levied on the value of goods and services sold (or the value of incomes paid or received). For example, excise taxes on fuel and other energy products are probably the

3) For instance, a tax on coal intended to reduce sulfur emissions will also affect manufacturers that use coal to extract chemicals for dyeing. If a tax were imposed on the sulfur content of coal, the manufacturers in the dyeing industry would unnecessarily be induced to switch to lower-sulfur coal or to find other sources of chemicals (Blackman and Harrington, 2000).

4) Political considerations or the practical problems of design and implementation such as who is to be taxed are often the most important factors that determine the types of policy tools employed (Barthold, 1994).

5) This does not necessarily imply that environmental output taxes are free from such institutional constraints, only that such constraints may be smaller for an output tax.

6) Smith (1996) points out that "where the assessment, collection, or enforcement of the tax can be 'piggy-backed' on to corresponding operations already established for existing taxes, the costs of an environmental tax measure may be significantly lower than where entirely-new administrative apparatus and procedures are required." 
most widespread environmental taxes mainly because of their administrative convenience (OECD, 1999a).

A comprehensive survey of the use of EIs (OECD, 1989) reports over 150 instances related to the purpose of environmental improvement in 14 OECD countries. However, many taxes and charges adopted partly for environmental reasons were mainly for the purpose of raising revenues. Other surveys show a rising trend in the use of EIs in developed countries. OECD (1994) reports the number of EIs increased almost 50 percent just from 1987 to 1991. Covering the years 1997-1999, OECD (1999b) shows that all of the OECD Member countries that responded to the questionnaire (24 out of 29) are using some types of EIs. This increasing trend has been maintained over the past decade. The number of environmentally related taxes in OECD countries has increased steadily. OECD (2006) reports that about 375 environmentally related taxes are currently being used in OECD countries, not counting other measures such as some 250 environmentally related fees and charges.

However, the popularity of EIs among developed countries often blurs the true nature of environmental instruments: many environmental taxes titled "emission charges or fees" usually are not exactly Pigouvian taxes, no matter what they are called. Difficulties in precisely monitoring the levels of pollutants force many developed countries to use less-ambitious charges or taxes on the bases that are easier to observe and enforce (OECD, 1999a). The political economy consideration of competitiveness also plays an important role when introducing and maintaining environmental taxes (OECD, 2006).

The situations in developing countries are not much different and might be worse.7) Technological constraints such as the use of dated technologies are mixed with structural

7) In addition to the difficulties with monitoring and enforcement of effective environmental policy instruments, many developing countries have distinct structural characteristics different from developed countries. They are often characterized by a large share of agriculture in total output and employment, and by large share of informal (or non-taxable) economic activities (Tanzi and Zee, 2000). Due to these constraints, many developing countries have relied heavily on indirect consumption taxes such as sales or excise taxes. This paper takes advantage of the fact that a uniform consumption tax on market output is equivalent to a uniform tax on market labor. 
constraints such as large numbers of small polluters that are hard to regulate, large traditional sectors, high bureaucratic cost, corruption, lack of political will, and severe shortage of budget and manpower. All these factors make it more difficult to implement EIs successfully. In short, the environmental governance systems in developing countries are not satisfactory. In China, for example, emission fees are charged on 20 different air pollutants. However, firms are required to pay fees only for the 'worst case pollutant,' even when more than one pollutant exceeds the permissible level. Other pollutants face no charge at the margin. ${ }^{8}$ ) Worsening these problems is that fees reduce firms' tax liabilities, and that 80 percent of fees are eventually returned to these firms. These problems cause perverse incentives for firms to perpetuate noncompliance (Blackman and Harrington, 2000).9)

Though the literature on environmental taxes is vast, it usually assumes that emissions can be perfectly observable, or that a tax on the consumption good or a tax on a market input corresponds exactly to a tax on emissions. An early example is Sandmo (1975). He examines the optimal tax rate when the aggregate amount of one of the consumption goods enters the utility function directly as a negative externality. Thus, he assumes that the relation between the output and the externality is fixed, where only changes in output level can reduce the emissions level. In this case, a tax on emissions is equivalent to a tax on the output of the polluting industry.

Cremer and Gahvari (2001) re-examine the results of Sandmo in the case where taxation of a consumption good is not equivalent to a tax on emissions. In a second-best world with distorting labor taxes, they show that taxes on emissions and on consumption

8) Furthermore, actual monitoring of emissions is based only on visual inspection of the clarity of flue gases. Actual fees are determined in combination with estimates of emissions volumes, but many studies point out that the emissions fees are well below marginal abatement costs for most firms and thus provide limited abatement incentives (Yang, et al., 1997).

9) In order to solve administrative difficulties in implementing an emissions tax, developing countries often rely on other policy instruments: product taxes on fuels in many countries, voluntary agreements and information disclosure such as the Clean River Program in Indonesia (O'Connor, 1998). However, the overall evaluation of experiences with EIs in many developing countries indicates that EIs have potentially increased technical and financial burdens on already-fragile institutional structures (Serôa da Motta, et al., 1999; McMorran and Nellor, 1994). 
goods can be set separately to address different objectives: an emission tax solves the externality problem while output taxes are determined in conformity with optimal tax considerations. However, they do not examine the magnitude of possible welfare losses from using an output tax instead of an emissions tax, since they still assume that a firm's emission level is fully observable.

Cropper and Oates (1992) have suggested that output taxes may be superior to an emissions tax if monitoring is costly. Schmutzler and Goulder (1997) explicitly examine the importance of monitoring costs in the choice between taxes on emissions and taxes on outputs (or inputs). Under imperfect monitoring, they show that output taxes might be preferred to emissions taxes if outputs are easily substitutable and abatement options are scarce. Hoel (1998) also argues that emission taxes may be no more effective than other policies if abatement costs are uncertain and non-convex, and if measuring emissions is difficult.

Vatn (1998) approaches the problem in a different way. Using a material balance perspective in his model, he assumes that all economic activities such as extraction, production, and consumption generate emissions. Normally, it becomes harder and more expensive to detect and mitigate them in the later stages of economic activities, since emissions become part of numerous inputs and outputs. If transaction costs nternalizing the externalities outweigh the gains from hitting the target more precisely by using an emissions tax, the use of input-oriented taxes might be more efficient. ${ }^{10)}$

To compare alternative taxes, Fullerton, et al. (2001) start by showing theoretically and numerically that the emissions tax raises welfare more than an output tax. They do not explicitly measure or model the costs of targeting the tax on pollution, such as the costs of measurement, monitoring, and enforcement, but their numerical simulation results show how big those costs must be to justify the use of the output tax instead. In a more direct comparison, Smulders and Vollebergh (2001) explore the trade-off between

10) Broadly speaking, transaction costs include monitoring, enforcement, and other controlling costs incurred by the environmental authorities. 
incentive effects and administrative costs associated with the implementation of various environmental tax instruments. They find that the output tax might be favored if emissions are closely linked to the uses of output, if other technological abatement methods are not plentiful, and if administrative costs of the emissions tax are high. Others argue that output or input taxes such as fuel taxes can be quite effective to control air pollution in developing countries if accompanied by emissions standards to stimulate cleaner technologies (Eskeland, 1995; Eskeland, et al., 1998).

In a broad sense, the abilities of coping with various structural difficulties can be considered as public good. López (2006) argues that decentralization and transparency in decision making, due process, and stakeholder participation in reform are essential to address these difficulties and the use of flexible instruments such as information mechanisms might be more promising in environmental policy design in developing countries. Blackman (2010) emphasizes the 'monitorability' in addition to the traditional policy principle of efficiency for the choice of economic instruments in developing countries. To overcome this problem, developing countries tend to depend heavily on nonregulatory pressures such as public discolure and voluntary regulation, but a large number of studies show inconclusive results at best. Somanathan (2010), however, points out that information discharge favored in many developing countries should be accompanied by strengthening regulation in order to reduce environmental risks.

\section{The Model}

The developing country model has three production sectors: two taxable manufacturing sectors $(X$ and $Y)$ and one non-taxable subsistence agricultural sector $(Z)$. This static model considers only one time period, with no saving decision. The $N$ identical households obtain utility from the clean manufactured good $(X)$, the dirty good $(Y)$, the clean agricultural good $(Z)$, a government-produced public good $(G)$, and environmental quality $(E)$. 
The household allocates a fixed amount of time $(\bar{L})$ between taxable labor $(L)$ and non-taxable labor $\left(L_{Z}\right)$. For simplicity, I refer to the resource as time available for labor supply, but more generally, it can be a fixed total amount of all resources such as labor, capital, land, and energy. In that case, $L$ can be interpreted as the resources used in the market, where $L_{Z}$ is the amount used for subsistence agriculture. This reflects not only the conceptual problems in measuring agricultural income for taxation, but also administrative difficulties in monitoring and enforcement of that tax.11) Therefore, I assume that $Z$ is non-taxable. ${ }^{12)}$

The clean good is produced with a constant returns to scale production technology using only labor $\left(L_{X}\right)$, while a dirty good is produced with a constant returns to scale production technology using labor $\left(L_{Y}\right)$ and emissions $(D)$ :

$$
X=L_{X}
$$

and $Y=F\left(L_{Y}, D\right)$.

For convenience, a unit of $X$ is defined as the amount that can be produced using one unit of labor. The numeraire is labor (or equivalently, $X$ ).

The agricultural sector produces a non-taxable clean good $(Z)$ with constant returns to scale technology using only labor as an input:

$$
Z=L_{Z}
$$

11) The governments in many developing countries often have difficulties in finding suitable tax tools, especially when the transaction arises within the household or between households using informal markets. In this sense, a non-taxable clean agricultural good (Z) might be interpreted instead as all informal economic activities. See Schneider and Enste (2000) for an empirical assessment of the size of the underground economy for developing countries as well as OECD countries.

12) It is well known that many countries exempt consumption taxes on foods and other agricultural products for the purpose of income distribution. 
where a unit of $Z$ is defined as the amount that can be produced using one unit of labor.

Both manufacturing outputs are assumed to be taxable. For environmental reasons, the output of the polluting sector $(Y)$ might be taxed at a rate higher than that of the non-polluting sector $(X)$. This paper will focus on the differential, that is, the extra tax on the output of the dirty industry. In addition, note that any uniform tax on outputs $X$ and $Y$ is equivalent to a tax on labor used in those two sectors, since labor is the only source of income in this model. For these reasons, this model will use a tax on labor $\left(t_{L}\right)$ to represent the uniform or common portion of the output taxes on $X$ and $Y$. Then, the output tax on a dirty consumption good $\left(t_{Y}\right)$ is the extra tax on output of the dirty industry.

Emissions $(D)$ are a dirty input that can be disposal of gaseous, liquid, and solid waste used to produce output. Note that the production function for $Y$ has variable pollution, $D$ per unit of output. This disposal is assumed to inflict some private cost on producers in terms of resources (labor), and a unit of emissions can be defined as the amount that requires one unit of resources:

$$
D=L_{D}
$$

Thus, the firm has constant private marginal cost of pollution, equal to one, so it chooses a finite amount of pollution. Because of the negative externality, however, the firm's choice is not socially optimal. Aggregate emissions $(N D)$ have a harmful effect on overall environmental quality $(E)$ :

$$
E=e(N D)
$$

where $e^{\prime} \equiv \frac{\partial e}{\partial D}<0$. The model also assumes perfect competition, certainty, complete information, and perfect factor mobility between sectors. 
Government produces a public good using labor:

$$
G=N L_{G}
$$

Government finances the public good with the tax on market labor $\left(t_{L}\right)$ and the output tax on a dirty consumption good $\left(t_{Y}\right)$, and possibly a tax on emissions $\left(t_{D}\right)$. Hence, the government budget constraint is

$$
G=N\left(t_{L} L+t_{Y} Y+t_{D} D\right)
$$

For convenience, the consumer price for the polluting manufactured good $\left(c_{Y}\right)$ is defined as the sum of the producer price $\left(p_{Y}\right)$ and the output tax $\left(t_{Y}\right)$. The nominal wage is normalized to one, and $p_{X}=p_{Z}=1$ as well. Without loss of generality, assume that the initial producer price of $Y$ is normalized to one (i.e., $p_{Y}=1$ ).

Finally, the economy's overall resource constraint is given by

$$
N L=N X+N\left(L_{Y}+D\right)+G
$$

A representative household maximizes the utility function $U=U(X, Y, Z ; G, E)$, subject to the budget constraint $\left(1-t_{L}\right) L=X+\left(1+t_{Y}\right) Y$. Taxable labor supply is given by $L=L_{X}+L_{Y}+L_{D}+L_{G}$. From the first-order conditions, we have $U_{X}=\frac{U_{Y}}{\left(1+t_{Y}\right)}=\frac{U_{Z}}{\left(1-t_{L}\right)}=\lambda$, where a subscript on $U$ denotes a marginal utility from that good (e.g., $U_{Z}$ is the partial derivative of $U$ with respect to $L_{Z}$ ), and $\lambda$ is the private marginal utility of income. ${ }^{13)}$

13) In the representative household's utility maximization, it is assumed that she considers the environmental quality $(E)$ and the public good $(G)$ to be independent of her own choices. This assumption is appropriate if the number of consumers $(N)$ is large. 
Using log-linearization techniques, appropriate for small changes, I derive equations that show the impacts of a tax change on prices, quantities, and welfare.

In general, I start at an initial competitive equilibrium with possible pre-existing $t_{L}, t_{Y}$, and $t_{D}$. Special cases are considered where one or more of those taxes are not possible (i.e., are set to zero). The model then can be used to show all of the effects of a small increase in the emissions tax or if that is not possible, then a small increase in the output tax. In all cases, the revenue is returned through a reduction in the pre-existing tax on market labor so that $G$ is not affected $(d G=0)$. The effect of any such change on utility can be expressed by totally differentiating the household's utility function:

$$
d U=U_{X} d X+U_{Y} d Y-U_{Z} d L+N U_{E} e^{\prime} d D
$$

Totally differentiate the overall resource constraint (8), divide it by $N$, and set $d G=0$, to get:

$$
d X=d L-d L_{Y}-d D
$$

Next, plug the first-order conditions from the utility maximization into (9), and divide it by the Lagrange multiplier $(\lambda)$, to get:

$$
\frac{d U}{\lambda}=d X+\left(1+t_{Y}\right) d Y-\left(1-t_{L}\right) d L-\mu d D
$$

where $d U$ is the change in a representative household's utility. The term $\mu$ equals $-N U_{E} e^{\prime} / \lambda$ and denotes the MED from emissions.

Totally differentiate the production function of the dirty good (2):

$$
d Y=F_{L_{Y}} d L_{Y}+F_{D} d D
$$


where $F_{i} \equiv \partial F(\cdot) / \partial i$ for $i=L_{Y}$ and $D$. Then, substitute the first-order conditions from the profit maximization into (12) to get:14)

$$
d Y=d L_{Y}+\left(1+t_{D}\right) d D
$$

Finally, plug (13) into (11) and divide the both sides of the equation by $L$. then

$$
\frac{d U}{\lambda L}=t_{L} \hat{L}+t_{Y}\left(\frac{Y}{L}\right) \hat{Y}+\left(t_{D}-\mu\right)\left(\frac{D}{L}\right) \hat{D}
$$

where a hat over a variable denotes a percentage change (e.g., $\hat{L} \equiv d L / L$ ). The left hand side of this expression is the change in welfare in terms of a particular monetary unit $(d U / \lambda)$ as a fraction of the total return to market labor in the economy $(L)$. The right hand side consists of three parts. The first and second parts are the welfare effects of the environmental policy through its impact on the amount of the market labor $(\hat{L})$ and the dirty manufactured good $(\hat{Y})$. The third term is the welfare impact resulting from the change in pollution $(\widehat{D})$. Note that if either a tax on the market labor $\left(t_{L}\right)$ or the extra consumption tax on the dirty good $\left(t_{Y}\right)$ is set to zero, then the corresponding welfare effect disappears from the equation. Also note that, even without any pre-existing taxes $\left(t_{L}=t_{Y}=0\right)$ in theory, the developing country can successfully internalize the externality by imposing a Pigouvian tax on emissions $\left(t_{D}\right)$ equal to the MED $(\mu)$. The rate $t_{D}=\mu$ then maximizes utility $(d U=0)$.

Next, totally differentiate the government budget constraint (7), divide it by the total amount of labor supply in the manufacturing sectors $(N L)$, hold $G$ fixed $(d G=0)$, and divide it again by $\left(1-t_{L}\right)$ to get:

14) Maximizing the profit function $\Pi=F\left(L_{Y}, D\right)-L_{Y}-\left(1+t_{D}\right) D$ gives the first-order conditions: $F_{L_{Y}}=1$ and $F_{D}=\left(1+t_{D}\right)$. 


$$
\begin{gathered}
\hat{t_{L}}=-\left(\frac{t_{L}}{1-t_{L}}\right) \hat{L}-\frac{\left(1+t_{Y}\right) Y}{\left(1-t_{L}\right) L}\left[\widehat{t_{Y}}+\left(\frac{t_{Y}}{1+t_{Y}}\right) \hat{Y}\right] \\
-\frac{\left(1+t_{D}\right) D}{\left(1-t_{L}\right) L}\left[\widehat{t_{D}}+\left(\frac{t_{D}}{1+t_{D}}\right) \hat{D}\right],
\end{gathered}
$$

where $\widehat{t_{L}} \equiv d t_{L} /\left(1-t_{L}\right), \widehat{t_{D}} \equiv d t_{D} /\left(1-t_{D}\right)$ and $\widehat{t_{Y}} \equiv d t_{Y} /\left(1+t_{Y}\right)$. This is the change in $t_{L}$ necessary for government to balance the budget when changing $t_{Y}$ or $t_{D}$. To evaluate this expression, the next step is to solve for $\hat{L}, \hat{Y}$ and $\hat{D}$ in terms of two environmental tax instruments: $\widehat{t_{Y}}$ and $\widehat{t_{D}}$.

In order to find analytical solutions to (14) and (15), one needs to make some assumptions on consumer preferences. In particular, assume that environmental quality $(E)$ and the public good $(G)$ are separable from the consumption goods $X, Y$ and $Z$ and that the consumption goods enter utility in a homothetic sub-utility function as in Bovenberg and de Mooij (1994) or Fullerton and Metcalf (2001):

$$
U(X, Y, Z ; G, E)=U(V(Q(X, Y), Z), G, E)
$$

where $V(\cdot)$ and $Q(\cdot)$ are both homothetic. For later use, define $p_{Q}$ as a price index on $Q(X, Y)$ such that

$$
p_{Q} Q=p_{X} X+c_{Y} Y
$$

and let $w$ be the real net wage, $w=\left(1-t_{L}\right) / p_{Q}$.

Totally differentiate (17) and divide it by $p_{Q}$ to get:

$$
p_{Q}=\frac{Y}{\left(1-t_{L}\right) L} \widehat{p_{Y}}+\frac{\left(1+t_{Y}\right) Y}{\left(1-t_{L}\right) L} \widehat{t_{Y}} .
$$


Since $p_{X}=1$ always, the change in the overall price index $\left(\widehat{p_{Q}}\right)$ depends on the change in the producer price of a dirty good $\left(\widehat{p_{Y}}\right)$ and/or the change in its output tax $\left(\widehat{t_{Y}}\right)$.

For the change in the producer price of a dirty output $\left(\widehat{p_{Y}}\right)$, Appendix A shows how to use the zero-profit condition and the first-order conditions from profit maximization to obtain:

$$
\widehat{p_{Y}}=\frac{\left(1+t_{D}\right) D}{Y} \widehat{t_{D}}
$$

Substitute (19) into (18) to get:

$$
\widehat{p_{Q}}=\frac{\left(1+t_{Y}\right) Y}{\left(1-t_{L}\right) L} \widehat{t_{Y}}+\frac{\left(1+t_{D}\right) D}{\left(1-t_{L}\right) L} \widehat{t_{D}}
$$

This equation says that an increase in either $t_{Y}$ or $t_{D}$ results in an increase in the overall price index, and that the contribution of each depends on the expenditure shares of $Y$ and $D$ in after-tax labor income from the manufacturing sectors.

The definition of the real wage rate implies that $\hat{w}=-\widehat{t_{L}}-\widehat{p_{Q}}$. Thus:

$$
\widehat{w}=-\widehat{t_{L}}-\frac{\left(1+t_{Y}\right) Y}{\left(1-t_{L}\right) L} \widehat{t_{Y}}-\frac{\left(1+t_{D}\right) D}{\left(1-t_{L}\right) L} \widehat{t_{D}} .
$$

This equation says that the real net wage decreases if any tax were to increase. Again, the contribution to the change in the real net wage depends on each expenditure share. Substitute (15) into (21) to get:

$$
\hat{w}=\frac{t_{L}}{\left(1-t_{L}\right)} \hat{L}+\frac{t_{Y} Y}{\left(1-t_{L}\right) L} \hat{Y}+\frac{t_{D} D}{\left(1-t_{L}\right) L} \hat{D} .
$$


Subsistence agriculture $(Z)$ is non-taxable and therefore operates in this model much like home production such as work in the household cooking, cleaning, child care, and gardening to grow food for the family. Therefore, the choice between market labor and home/agricultural labor acts in this model much like a labor-leisure choice in other models such as Bovenberg and de Mooij (1994) and Fullerton and Metcalf (2001). Thus, the next step is the derivation of a "labor supply" function, meaning the supply of labor to the market manufacturing sectors rather than to the non-market home/agricultural sector.

Maximization of the household's sub-utility for the composite manufactured good $(Q)$ and a clean agricultural good $(Z)$ subject to the budget constraint $(Q=w L)$ gives the function for the supply of labor to the manufacturing sectors, $L=L(w)$, and totally differentiating it yields:

$$
\hat{L}=\epsilon \hat{w}
$$

where $\epsilon$ is the uncompensated elasticity of this labor supply in the manufacturing sectors with respect to the net wage (i.e., $\epsilon \equiv \frac{w}{L} \frac{\partial L}{\partial w}$ ).

The equations above can be used to solve for any change as a function of the exogenous tax change, exogenous parameters, and initial values of the variables. Appendix B shows how these equations are used to solve for the key variables $(\hat{D}, \hat{Y}, \hat{L})$.

First, the change in emissions can be expressed as follows:

$$
\hat{D}=-\Theta\left\{\begin{array}{c}
\sigma_{Q}(1-\phi)\left[1-(1+\epsilon) t_{L}\right] \widehat{t_{Y}} \\
+\left[\begin{array}{c}
\sigma_{Q}(1-\phi)\left[1-(1+\epsilon) t_{L}\right] \frac{\left(1+t_{D}\right) D}{\left(1+t_{Y}\right) Y} \\
+\sigma_{Y}\left(\frac{L_{Y}}{Y}\right)\left[1-(1+\epsilon)\left(t_{L}+t_{Y} \frac{Y}{L}\right)\right]
\end{array}\right] \widehat{t_{D}}
\end{array}\right\},
$$


where $\phi \equiv \frac{\left(1+t_{Y}\right) Y}{\left(1-t_{L}\right) L}$ and $\left.\Theta \equiv\left\{1-(1+\epsilon)\left[t_{L}+t_{Y}\left(\frac{Y}{L}\right)+t_{D}\left(\frac{D}{L}\right)\right]\right\}^{-1} \cdot{ }^{15}\right)$

Note that the $\sigma_{Q}$ part of $\widehat{t_{D}}$ term is similar to the $\widehat{t_{Y}}$ term. They represent the substitution in consumption. The $\sigma_{Y}$ part of $\widehat{t_{D}}$ term represents the substitution in inputs for production.

For $\hat{Y}$ :

$$
\hat{Y}=-\Theta\left\{\begin{array}{c}
\sigma_{Q}(1-\phi)\left[1-(1+\epsilon) t_{L}\right] \widehat{t_{Y}} \\
+\left[\begin{array}{c}
\sigma_{Q}(1-\phi)\left[1-(1+\epsilon) t_{L}\right] \frac{\left(1+t_{D}\right) D}{\left(1+t_{Y}\right) Y} \\
+\sigma_{Y}\left(\frac{L_{Y}}{Y}\right)(1+\epsilon) t_{D}\left(\frac{D}{L}\right)
\end{array}\right] \widehat{t_{D}}
\end{array}\right\} .
$$

Since both $\hat{D}$ and $\hat{Y}$ are used in the key welfare equation (14), these two equations ((24) and (25)) deserve further discussion. First, note that both equations have the same term for an incremental tax change of the output tax (i.e., the $\widehat{t_{Y}}$ term). It shows that if the developing country government increases (or introduces) $t_{Y}$ marginally and holds the level of the Pigouvian tax fixed (i.e., $\widehat{t_{D}}=0$ ), the effects on both the dirty input $(D)$ and a dirty output $(Y)$ are the same in magnitude (i.e., $\hat{Y}=\widehat{D})$. Holding $\widehat{t_{D}}=0$ means that the government cannot (or need not) use the Pigouvian tax as an instrument for environmental improvement. This result just reflects the fact that the output tax change $\left(\widehat{t_{Y}}\right)$ will reduce output. No change in relative input prices $\left(\widehat{t_{D}}=0\right)$ means that both inputs will be reduced in the same proportion $\left(\widehat{Y}=\widehat{D}=\widehat{L_{Y}}\right)$.

15) One important assumption is that the denominator of (25) must be positive (i.e., $\Theta>0$ ). It means that the government is on the upward-sloping side of the Laffer curve for wage taxation. Since $G / N L=t_{L}+t_{Y}(Y / L)+t_{D}(D / L)$ from the government's budget constraint, this assumption means that the following condition needs to be satisfied: $\epsilon<(N L-G) / G$. This means that $\epsilon$ should be bounded above by the ratio of private output to government output. This follows from the fact government spending is financed by taxes. 
Next consider the second terms in (24) and (25) that are multiplied by $\widehat{t_{D}}$. This change in relative input prices can affect $D$ differently than $Y$, but only when $\sigma_{Y}$ is not zero. With substitution in production, the firm can reduce pollution more than output $(\widehat{D} \neq \hat{Y})$ and change pollution per unit of output, by an extent that increases with $\sigma_{Y}$. To clarify, note that if $\sigma_{Y}=0$ in (24) and (25), then $\widehat{t_{D}}$ has the exact same effect on $\widehat{D}$ as an $\hat{Y}$. This corresponds to the special case where the dirty good itself generates externalities either in production or in consumption. Equivalently, suppose that pollution per unit of output is fixed. Then, the tax on a dirty output has the same effect on that output as it has on the dirty input. For example, final consumption goods such as gasoline and cigarettes may have environmental problems that come not from one of the inputs to production, but from the use of the final consumption good, so the pollution per unit of output is fixed. Therefore, $\hat{Y}=\hat{D}$, so the government can achieve the same amount of reduction in pollution either by imposing an output tax or tax on pollution. In general, however, this model does allow for substitution $\left(\sigma_{Y} \neq 0\right)$.

Finally, for $\hat{L}$ :

$$
\hat{L}=-\Theta \epsilon\left\{\begin{array}{c}
\sigma_{Q}(1-\phi)\left[t_{Y}\left(\frac{Y}{L}\right)+t_{D}\left(\frac{D}{L}\right)\right] \widehat{t_{Y}} \\
+\left[\begin{array}{c}
\sigma_{Q}(1-\phi)\left[t_{Y}\left(\frac{Y}{L}\right)+t_{D}\left(\frac{D}{L}\right)\right] \frac{\left(1+t_{D}\right) D}{\left(1+t_{Y}\right) Y} \\
+\sigma_{Y}\left(\frac{L_{Y}}{Y}\right) t_{D}\left(\frac{D}{L}\right) \widehat{t_{D}}
\end{array}\right]
\end{array}\right\}
$$

Since $\Theta>0, \epsilon>0$ and all of the terms inside the large brackets are positive, an increase in either $t_{Y}$ or $t_{D}$ does reduce labor use in the manufacturing sectors. Note that I do not preclude the possibility of 'double-dividend' in that lowering $t_{L}$ with additional revenues from $t_{Y}$ and/or $t_{D}$ results in more employment. However, in this paper I only consider the case of introducing new environmental tax or raising the rate of pre-existing 
environmental tax. Therefore, in (26) the change in labor $(\hat{L})$ results from $\widehat{t_{Y}}$ and/or $\widehat{t_{D}}$. Now, the equation (26) completes the solution for the necessary variables $(\hat{D}, \hat{Y}$ and $\hat{L})$ to enter the key equation (14) for the change in welfare of the economy.

If non-taxable production is clean as assumed, then environmental tax policy could generate further reductions in pollution levels through the indirect channel of reduced labor supply to taxable sectors. If instead subsistence agriculture is polluting, then environmental policy using tax instruments could cause an unwanted increase in the overall level of pollution. Moreover, the environmental problem could become worse, since pollution generated in the non-taxable sector cannot be regulated at all. This kind of dilemma arises when controlling inputs rather than emissions: if all inputs cannot be regulated, partial application of sub-optimal input taxes might result in unwanted substitutions among inputs and therefore might aggravate the problem.

However, it is unclear whether the sector $Z$ is environmentally benign. In many developing countries, agricultural (or traditional) sectors have both characteristics: on the one hand, they usually employ environmentally-benign production technology such as less use of chemical fertilizer and tilling the soil with animals. In that case, environmental tax policy could achieve further reduction in the overall pollution level in the society by shifting labor to non-market activity. On the other hand, some developing countries like Brazil have been trying hard to reduce harmful farming activities such as slash-and-burn farming. In that case, the effect could be the opposite. 16)

\section{Environmental Tax Reforms and Optimal Tax Rates}

\section{Environmental Tax Reforms}

Suppose that the government of a developing country is considering a tax reform by

16) Eskeland and Jimenez (1992) point out that small firms in the informal sector are often major polluters in developing countries. If I interpret $Z$ as the informal sector rather than as subsistence farming, then that increases the probability of an unwanted increase in the overall pollution level. 
raising (or introducing) $t_{Y}$ with pre-existing labor tax, holding $t_{D}$ fixed (i.e., $t_{L}>0$, $t_{D} \geq 0, t_{Y} \geq 0$, and $\widehat{t_{Y}}>0$ but $\left.\widehat{t_{D}}=0\right)$. Then, substituting (24), (25), and (26) into (14):

$$
\frac{d U}{\lambda L}=-\Theta\left[\sigma_{Q}(1-\phi)\left(1-t_{L}\right) A\right] \widehat{t_{Y}}
$$

where $A \equiv t_{Y}(Y / L)+t_{D}(D / L)-\left\{1-\epsilon\left[t_{L} /\left(1-t_{L}\right)\right]\right\} \mu(D / L)$.

Note that this incremental tax reform has no substitution effect between inputs. Though $\sigma_{Y}$ is still non-zero, it is not relevant for $\widehat{t_{Y}}$. By imposing this additional output tax, the government can reduce the consumption level of a dirty good, but it cannot induce the producers to substitute other cleaner inputs for emissions in production. Therefore, the change in $t_{Y}$ has no substitution effect in production (i.e., $\sigma_{Y}$ does not appear in (27)). Also note how the formula simplifies with no pre-existing taxes:

$$
\frac{d U}{\lambda L}=\sigma_{Q}\left(1-\frac{Y}{L}\right) \mu\left(\frac{D}{L}\right) \widehat{t_{Y}}
$$

Welfare is always increased by a small increase in the output tax from zero if $\sigma_{Q}>0$. However, as will be shown later, the magnitude of the net welfare effect from the output tax is smaller than that of the Pigouvian tax, due to the lack of a substitution effect.

Next, suppose the government raises (or introduces) $t_{D}$ with the pre-existing labor tax, holding $t_{Y}$ fixed (i.e., $t_{L}>0, t_{Y} \geq 0, t_{D} \geq 0$, and $\widehat{t_{D}}>0$ but $\widehat{t_{Y}}=0$ ). Then, the welfare expression (14) simplifies:

$$
\frac{d U}{\lambda L}=-\Theta\left\{\sigma_{Q}(1-\phi)\left(1-t_{L}\right)\left[\frac{\left(1+t_{D}\right) D}{\left(1+t_{Y}\right) Y}\right] A+\sigma_{Y}\left(\frac{L_{Y}}{Y}\right) B\right\} \widehat{t_{D}}
$$


where $B \equiv t_{Y}(Y / L) \mu(D / L)+\left(1-t_{L}\right)\left\{t_{D}(D / L)-\left[1-\epsilon\left(t_{L} /\left(1-t_{L}\right)\right)\right] \mu(D / L)\right\}$.

The first term in the large brackets represents the output effect as before (i.e., the substitution in consumption from $\sigma_{Q}$ ). The second term is the substitution effect in production from $\sigma_{Y}$ : the producers can substitute one input for another as the relative input prices change due to $\widehat{t_{D}}$. In other words, a small increase in the $t_{D}$ raises the consumer price for $Y$ and the consumers moves away from $Y$ to $X$ (and possibly to $Z$ ) due to higher price. As a result, the environmental quality improves and the welfare rises.

However, the output effect from $t_{D}$ is smaller than the same effect from $t_{Y}$. Though similar to equation (27) in appearance, the first term in the large brackets (i.e., the $\sigma_{Q}$ term) of equation (28) has an additional multiplicative term $\left(1+t_{D}\right) D /\left(1+t_{Y}\right) Y$ in it. This is the ratio of expenditure on the dirty input to the revenue from selling the output, and it is always less than one. Thus, the output effect from $t_{D}$ is always smaller than the same effect from $t_{Y}$.

The real strength of $t_{D}$, however, comes not from the output effect, but from the substitution effect. Unlike $\widehat{t_{Y}}$ back in equation (27), the Pigouvian tax in (28) penalizes the use of $D$ and induces the producers of $Y$ to shift into more use of $L_{Y}$. This ability to abate emissions by input substitution is a very powerful way to improve the environment, and other things being equal, it thus increases the overall social welfare. As I will show later in the numerical simulation, the size of $\sigma_{Y}$ is very important to decide the size of welfare gain. ${ }^{17)}$ However, many developing countries appear to have much lower $\sigma_{Y}$ than in developed countries. For example, global coal use over the next two decades is expected to rise more than 50 percent, mostly in the developing world and especially in Asia. Coal now makes up 67 percent of China's total primary energy

17) However, I am not saying that $\sigma_{Y}$ is the only factor that determines the size of welfare gain from using environmental taxes. And even if some developing countries show the same (or higher) levels of $\sigma_{Y}$ than developed countries, the potential welfare gain from using environmental taxes seems still smaller compared to that in developed countries. I will return to this point later parts (decomposition and sensitivity analysis) in the paper. 
consumption as of 2012 and this heavy dependence on coal has been fast rising: a 243 percent increase during the period of 2000 2011. In particular, industry accounts for 95 percent of China's coal use. Production and supply of electric power and heat power consume about 50 percent of China's coal (National Bureau of Statistics China, 2013). This explains why the Chinese $\mathrm{SO}_{2}$ and $\mathrm{NO}_{\mathrm{X}}$ emissions by 50 percent between 1996 and 2003 (UNEP, 2007). Hence, developing countries have difficulties in switching to more efficient and less polluting production technologies.

\section{Optimal Tax Rates}

Now I explicitly solve for the optimal tax rates for both $t_{Y}$ and $t_{D}$ and briefly discuss their implications. First, the second-best optimal tax on emissions $\left(t_{D}^{*}\right)$ with pre-existing $t_{L}$ only can be obtained from (28) by setting $d U=0$ and $t_{Y}=0$ :

$$
t_{D}^{*}=\mu\left[1-\epsilon\left(\frac{t_{L}}{1-t_{L}}\right)\right]
$$

Note that $t_{D}^{*}<\mu$ since $\left[1-\epsilon\left(\frac{t_{L}}{1-t_{L}}\right)\right]<1$, unless $t_{L}=0$ or $\epsilon=0$, which is consistent with Bovenberg and de Mooij (1994). As Fullerton, et al. (2001) point out, (29) can be rewritten as follows:

$$
t_{D}^{*}=\frac{\mu}{\Psi}
$$

where Goulder and Williams (1999) show that the partial equilibrium marginal cost of public funds $(\Psi)$ is $\left[1-\epsilon\left(\frac{t_{L}}{1-t_{L}}\right)\right]^{-1}$.

With pre-existing $t_{L}$ and $t_{Y}$, the third-best optimal tax rate on emissions $\left(t_{D}^{* *}\right)$ looks 
much more complicated. Before solving it explicitly, it can be shown that $t_{D}^{* *}$ is still less than the MED. Define $\theta \equiv\left(1+t_{D}^{* *}\right)(D / Y)$, which is the pollution intensity of $Y$ at $t_{D}^{* *}$ from (29a). ${ }^{18)}$ Rewrite (28) with $d U=0$ to make a basic point:

$$
\left(t_{D}^{* *}-\mu\right)=-\left\{\begin{array}{l}
\theta \sigma_{Q}(1-\phi)\left(\frac{Y}{D}\right)\left[\left(1-t_{L}\right) t_{Y}+\epsilon t_{L} \mu\left(\frac{D}{Y}\right)\right] \\
+(1-\theta) \sigma_{Y}\left(1+t_{Y}\right) \mu\left[(1+\epsilon) t_{Y}\left(\frac{Y}{L}\right)+\epsilon t_{L}\right] \\
\left(1-t_{L}\right)\left[\theta \sigma_{Q}(1-\phi)+(1-\theta) \sigma_{Y}\left(1+t_{Y}\right)\right]
\end{array}\right\} .
$$

Since the right-hand side of (30) is always negative, the third-best optimal Pigouvian tax with pre-existing $t_{L}$ and $t_{Y}$ is less than the social MED $(\mu)$.

The explicit analytical solution for $t_{D}^{* *}$ is much more complicated, because the $t_{D}^{* *}$ term appears in the both sides of (30). However, a positive and real value of the root of $t_{D}^{* *}$ can be obtained as follows:

$$
t_{D}^{* *}=\frac{-\left(\alpha \sigma_{Q}+\beta \sigma_{Y}\right)+\sqrt{\left(\alpha \sigma_{Q}+\beta \sigma_{Y}\right)^{2}-4 \gamma \sigma_{Q}\left(\delta \sigma_{Q}+\kappa \sigma_{Y}\right)}}{2 \gamma \sigma_{Q}},
$$

where $\quad \alpha \equiv(1-\phi)\left(\frac{D}{Y}\right)\left[\left(1-t_{L}\right)\left(\frac{D}{L}\right)+\left(1-t_{L}\right) t_{Y}\left(\frac{Y}{L}\right)-\left(1-t_{L}-\epsilon t_{L}\right) \mu\left(\frac{D}{L}\right)\right]$,

$$
\begin{aligned}
& \beta \equiv\left(1-t_{L}\right)\left(\frac{D}{L}\right)\left(1+t_{Y}\right)\left(\frac{L_{Y}}{Y}\right), \gamma \equiv(1-\phi)\left(\frac{D}{Y}\right)\left(1-t_{L}\right)\left(\frac{D}{L}\right), \\
& \delta \equiv(1-\phi)\left(\frac{D}{Y}\right)\left[\left(1-t_{L}\right) t_{Y}\left(\frac{Y}{L}\right)-\left(1-t_{L}-\epsilon t_{L}\right) \mu\left(\frac{D}{L}\right)\right], \\
& \text { and } \kappa \equiv\left(1+t_{Y}\right)\left(\frac{L_{Y}}{Y}\right) \mu\left(\frac{D}{L}\right)\left[(1+\epsilon) t_{Y}\left(\frac{Y}{L}\right)-\left(1-t_{L}-\epsilon t_{L}\right)\right] \\
& \text { for }\left(\alpha \sigma_{Q}+\beta \sigma_{Y}\right)^{2} \geq 4 \gamma \sigma_{Q}\left(\delta \sigma_{Q}+\kappa \sigma_{Y}\right) .
\end{aligned}
$$

18) Since $Y=F\left(L_{Y}, D\right)$, the remaining share of output is $(1-\theta) \equiv L_{Y} / Y$. 
Note the difference between the second-best optimal Pigouvian tax $\left(t_{D}^{*}\right)$ with pre-existing labor tax from (29) and the third-best one $\left(t_{D}^{* *}\right)$ with pre-existing labor and emissions taxes from (31). The $t_{D}^{*}$ only depends on the pre-existing $t_{L}, \epsilon$, and $\mu$. However, $t_{D}^{* *}$ becomes much more difficult to calculate. It is required for the environmental authority to have information on technological and structural parameters. In developing countries, however, many administrative problems such as poor record keeping, unreliable and insufficient data, and shortage of trained officials are widespread. Thus, this heavy requirement for additional information would make it more difficult to implement emissions tax in developing countries.

The third-best optimal tax on output $\left(t_{Y}^{* *}\right)$ with pre-existing $t_{L}$ and $t_{D}$, however, looks simpler. It can be obtained by setting the numerator of (28) to zero:

$$
t_{Y}^{* *}=\left[1-\epsilon\left(\frac{t_{L}}{1-t_{L}}\right)\right]\left(\mu-t_{D}\right)\left(\frac{D}{Y}\right) .
$$

Again, using the definition of the partial equilibrium marginal cost of public funds $(\Psi)$, the equation (32) can be rewrittend as follows:

$$
t_{Y}^{* *}=\left(\frac{\mu}{\Psi}\right)\left(\frac{D}{Y}\right)-t_{D}\left(\frac{D}{Y}\right)
$$

Note that if $t_{D}=0$, then (32a) collapses and $t_{Y}^{* *}=t_{Y}^{*}$ in the form:

$$
t_{Y}^{* *}=t_{Y}^{*}=\left(\frac{\mu}{\Psi}\right)\left(\frac{D}{Y}\right)=t_{D}^{*}\left(\frac{D}{Y}\right)
$$

which is the output effect from the second-best output tax. If $t_{Y}$ is employed, the economy has two different sources of distortions: first, the output tax increases the 
consumer price $\left(c_{Y}\right)$ so that demand for $Y$ decreases (if $\sigma_{Q}>0$ ). Second, the output tax raises the overall price level $\left(p_{Q}\right)$ so that the household reduces its demand for the composite consumption good $(Q)$ and, if $\epsilon>0$, increases the non-taxable agricultrual good $(Z)$. Snce $t_{D}$ has an output effect as well as the substitution effect, the second term in (32a) means that the tax rate $t_{Y}$ needs to be adjusted for the output effect already obtained from taxing emissions. Note that $t_{D}^{* *}=0$, if $t_{D}=\frac{\mu}{\Psi}$. In other words, if emissions are taxed optimally, then the tax rate on output should be zero. ${ }^{19)}$

Also note that if the optimal emissions tax $t_{D}^{*}$ is unavailable, and $t_{D}=0$, then equation (32b) says that the second-best optimal $t_{Y}$ is the desired emissions tax $\left(t_{D}^{*}\right)$ times emissions per unit of output $(D / Y)$. In other words, the second-best optimal $t_{Y}$ is equal to the social MED per unit of output. Fullerton, et al. (2001) discuss the implication of the similarity between $t_{D}^{*}$ and $t_{Y}^{*}$ : if the ideal emissions tax is unavailable, then the output ax should be set to generate exactly the same output effect as an ideal emissions tax provides.

An important policy implication of this result is that even if the authorities cannot tax emissions due to the difficulties of monitoring and enforcement or other administrative constraints, it does not mean that they have to over-tax the output. This point may be particularly relevant to many developing countries, since their monitoring and enforcement capabilities are less than in developed countries. They just need to know the ratio of the dirty input to the output $(D / Y)$, which can be obtained by estimating the general input structures of polluting firms. Furthermore, if firms are similar to each other in terms of their production technology, it would be much easier for the environmental authorities to obtain this ratio without much burden. Many developing countries have manufacturing sectors that consist of relatively less diverse industries than in developed countries. Factories in the same industry also usually share relatively homogeneous and

19) If $t_{D}$ is set sub-optimally and fixed, while $t_{Y}$ can vary, than $t_{Y}$ should be raised by the additional desired output effect to cover for under-taxation of emissions. 
simple production technology. If so, the effort to improve environmental quality in developing countries becomes less burdensome.

\section{Numerical Simulation}

In this section, the equations (27) and (28) are used to measure the impact on welfare of a small change in either $t_{D}$ or $t_{Y}$. This section employs parameter values from China, which in many respects has structural characteristics commonly found in many developing countries: a large agricultural (or informal) sector, heavy dependence on indirect consumption taxes, widespread use of polluting inputs and out-dated technologies, and many geographically dispersed small point-source polluters such as Town and Village Enterprises. In the next subsection, various parameters are selected.

Remember that I use the parameter values from China as an example of developing countries. I do not claim that China be considered a prima facie representative developing country in every possible respect. No single country can be considered to have all the institutional and structural characteristics in many developing countries over the world. I only say that China has some institutional and structural characteristics relevant to the hypothesis presented in this paper. The same reservation is explicitly made for the U.S. used here as an example of developed countries

\section{Assumptions on Parameters}

To measure the impact on welfare of an incremental change in either $t_{Y}$ or $t_{D}$, the equations (27) and (28) require values for many elasticities, shares, and initial tax rates.

For $t_{L}$, I want a tax rate that applies to the income from all household resources supplied to the market. Although the top marginal personal income tax rate in China is 45 percent, the average taxpayer faces only a 15 percent marginal tax rate (Heritage Foundation, 2000). However, indirect consumption taxes such as the VAT, consumption 
tax, and excise taxes are usually applied to both clean and dirty manufacturing sectors in addition to the direct individual and corporate income taxes. ${ }^{20)}$ Currently, the VAT rate of 17 percent is applied to a large proportion of domestically-produced goods and services as well as to imported goods. However, the VAT is levied at a lower rate of 13 percent for the basic foodstuffs and agricultural goods. ${ }^{21)}$ Assuming that the VAT rate for foods and agricultural goods is the basic rate applied to every household regardless of economic activity, I safely choose 10 percent for the portion of tax burden from various indirect taxes. Therefore, the final rate for $t_{L}$ is 0.25 .

For $t_{Y}$, I need additional tax rate that applies only to the income from all market household resources engaged in polluting production activities $(Y)$. As mentioned above, the VAT is applied differently: the 17 percent rate applies to produced goods in $Y$, the 13 percent rate applies to in $X$, and untaxed subsistence agriculture is part of $Z$. Therefore, the difference between $Y$ and $X$ is 4 percent. However, I will safely assume 5 percent for $t_{Y}$, because some goods such as motor vehicles are taxed at a higher rate.

For the uncompensated wage elasticity of market labor supply $(\epsilon)$, I need a single value to represent an aggregate of all workers in the manufacturing sectors and all market labor supply effects from changes in wages of the manufacturing sectors. In the case of developed countries, the literature provides many estimates of the hours elasticity that are small (or negative) for males, and other estimates that are large and positive for females. Although no specific estimates of uncompensated wage elasticities are available for China, numerous studies such as Rosenzweig (1980) and Jacoby (1993) show that the magnitudes are not much different from those in developed countries. In this model, however, $\epsilon$ represents elasticity of supply to the market sector rather than the non-market sector. So, I believe $\epsilon=0.3$ reasonable value. I also vary these numbers for sensitivity analysis later.

20) The most up-to-date information about China's tax system and tax rates was retrieved from the various documents at the State Administration of Taxation of the People's Republic of China (http://www.chinatax.gov.cn/2013/n2925/n2959/c307248/content.html).

21) It is reduced further to 3 percent for goods and services provided by small-scale taxpayers. 
For $Y / L$, I calculate the proportion of the industries most responsible for pollution in total production. The data from the National Bureau of Statistics (2013) shows that the polluting industries constitute about 58 percent of GDP, so I use 0.58 for $Y / L$.22) Since the magnitude of $\phi$ depends on the pre-existing $t_{L}$ and $t_{Y}$ as well as $Y / L$, for example, the choices for those parameters imply that $\phi=0.81$ for $t_{L}=0.25$, and $\left.t_{Y}=0.05 .23\right) \mathrm{In}$ other words, these polluting goods are primarily manufacturing goods, so 58 percent of total output represents more than 80 percent of private consumption of polluting manufactured goods.

For $D / Y$, I want an aggregate share for pollution in the dirty output. In China, many households as well as private firms still depend heavily on polluting coal: the ratio of coal in total energy production is 76.5 percent during the period between 2001 and 2011. Based on this evidence and the final use part of the 2010 input-output table from National Bureau of Statistics of China (2013), I calculate that the ratio of polluting inputs in total polluting output is about 48 percent. So, I use the conservative number of $D / Y=0.40$ without giving false sense of precision.

Estimates for the elasticities of substitution in consumption $\left(\sigma_{Q}\right)$ and production $\left(\sigma_{Y}\right)$ are not available for the specific aggregation in this model. For the case of developed countries, such as the U.S., Fullerton and Metcalf (2001) and Fullerton, et al. (2001) assume that both elasticities are close to one, as is broadly consistent with the empirical literature on substitution in consumption and production. However, it might be too far-fetched to assume that the situation would be the same in developing countries: much anecdotal evidence indicates that those substitution elasticities may be much lower than in developed countries. Hence, considering these factors, the baseline simulation for China is assumed here to employ 0.50 for both $\sigma_{Q}$ and $\sigma_{Y}$. I also vary these numbers for

22) The polluting industries included are Production and Supply of Electric Power, Heat Power and Water; Coking, Gas and Processing of Petroleum; Chemical Industry; Manufacture of Nonmetallic Mineral Products; Manufacture and Processing of Metals and Metal Products; and Manufacture of Machinery and Equipment.

23) Recall that $\phi$ is defined as $\left(1+t_{Y}\right) Y /\left(1-t_{L}\right) L$. 
sensitivity analysis later.

Finally, the model requires a measure of MED $(\mu)$. World Bank (1997) estimates the economic damage caused by pollution in China amounts to 8 percent of domestic GDP. Jha and Whalley (2001) review some estimates of environmental costs in selected Asian countries. In particular, they report that China has estimated environmental costs that are 5.5 to 9.8 percent of GDP (where measured GDP includes $X$ and $Y$ but not $Z$ ). There also exist other studies that show higher MED: for example, Economy (2004) argues that the cost to the country's economy from environmental degradation, resource scarcities, and air and water pollution has been estimated to be about 12 percent of China's GDP. In that regard, 5.78 percent of GDP estimated by World Bank (2007) for the total cost of air and water pollution in 2003 can be hardly considered as overstated. Unfortunately, all these estimates are average damage rather than marginal damage. Moreover, these numbers are more comprehensive measures than those from developed countries. ${ }^{24)}$ Hence, considering these factors for the case of developing countries, I use 7 percent of GDP for the estimate of damages. Then, since $Y$ is assumed 58 percent of GDP, damages are about 12 percent of $Y$. Moreover, since $D / Y=0.40$, damages would be about 0.3 per unit of $D(\mu=0.30)$.

Table 1 summarizes the assumed parameter values for numerical simulation. The first column shows the parameter values for developing countries. The second column shows a different set of parameter values. This case represents more or less the case for developed countries: social marginal environmental damages are lower $(\mu=0.1)$, both substitution elasticities in consumption and production are higher $\left(\sigma_{Q}=\sigma_{Y}=1.0\right)$, marginal labor income tax rate is higher $\left(t_{L}=0.4\right)$, the ratio of polluting goods to total output is lower $(Y / L=0.3)$, and the ratio of polluting inputs to polluting output is

24) Unlike the studies on the environmental damages in developed countries such as Pearce and Turner (1990) on the Netherlands or Freeman (1982) on the U.S. Jha and Whalley (2001) include not only health and productivity losses from pollution in urban areas (1.7 to 2.5 percent of GDP) but also productivity losses due to soil erosion, deforestation, and land degradation, water shortage and destruction of wetlands (3.8 to 7.3 percent) into the category. 
comparable to that in developing counties $(D / Y=0.4) .25)$ I use this alternative set of parameter values to investigate how the size of net welfare gain from using emissions taxes is changed due to various structural constraints. For a measure of welfare, I use $d U / \lambda L$, the monetary value in yuan of the change in utility as a fraction of market income.

〈Table 1〉 Assumptions on parameter values for developing and developed countries

\begin{tabular}{c|c|c|c}
\hline \multicolumn{2}{c|}{ Parameter Values } & $\begin{array}{c}\text { Developing } \\
\text { Country } \\
\text { (e.g., China) }\end{array}$ & $\begin{array}{c}\text { Developed } \\
\text { Country } \\
\text { (e.g., the U.S.) }\end{array}$ \\
\hline$\mu:$ & Social marginal environmental damage (MED) & 0.30 & 0.10 \\
$\epsilon:$ & Uncompensated elasticity of market labor supply & 0.30 & 0.10 \\
\hline$\sigma_{Q}:$ & Substitution elasticity between outputs & 0.50 & 1.00 \\
$\sigma_{Y}:$ & Substitution elasticity between inputs & 0.50 & 1.00 \\
\hline$t_{L}:$ & Avg. marginal market labor income tax rate & 0.25 & 0.40 \\
$t_{Y}:$ & Avg. marginal output tax rate & 0.05 & 0.00 \\
$t_{D}:$ & Avg. marginal emissions tax rate & 0.00 & 0.00 \\
\hline$Y / L:$ & Ratio of polluting output to market labor & 0.58 & 0.30 \\
$D / Y:$ & Ratio of emissions to polluting output & 0.40 & 0.40 \\
\hline
\end{tabular}

\section{The Simulation Results}

Table 2 summarizes the simulation results. The first column shows the developing country case (e.g., China). The first-best Pigouvian tax on emissions would be $\mu=0.30$, but with a pre-existing tax on market labor $\left(t_{L}=0.25\right)$, the marginal cost of public funds $(\Psi)$ is 1.1111 , and the second-best tax on emissions $\left(t_{D}^{*}\right)$ is 0.27 from (29a). Since the pre-existing $t_{Y}$ is 0.05 , the second-best tax on emissions $\left(t_{D}^{* *}\right)$ with pre-existing $t_{L}$ and $t_{Y}$ is 0.241 from (31). Furthermore, since $D / Y=0.4$, equation (32b) says that the

25) These parameter values for developed countries are similar to those used in Fullerton, et al. (2001). The rationale for this alternative set of parameters can be found there. 
second-best tax on output $\left(t_{Y}^{*}\right.$ with $\left.t_{D}=0\right)$ is 0.108 . Note that $t_{Y}^{*}=t_{Y}^{* *}=0.108$ because the pre-existing $t_{D}$ is assumed to be zero.

On the other hand, the second column shows the developed country case (e.g., the U.S.). Since $\mu=0.10$ for this case, the first-best $t_{D}$ would be 0.10 . The second-best tax on emissions $\left(t_{D}^{*}\right)$ is 0.0933 , since $\Psi=1.0714$ with a pre-existing $t_{L}=0.40$. The second-best tax on output $\left(t_{Y}^{*}\right)$ is 0.0373 .

$\langle$ Table 2〉 Simulation results

\begin{tabular}{|c|c|c|}
\hline & $\begin{array}{c}\text { Developing } \\
\text { Country } \\
\text { (e.g., China) }\end{array}$ & $\begin{array}{c}\text { Developed } \\
\text { Country } \\
\text { (e.g., the U.S.) }\end{array}$ \\
\hline \multicolumn{3}{|l|}{ Pre-existing tax rates (in rate) } \\
\hline$t_{L}$ & 0.25 & 40 \\
\hline$t_{Y}$ & 0.05 & 0 \\
\hline$t_{D}$ & 0 & 0 \\
\hline \multicolumn{3}{|l|}{ Second-best optimal tax rates (in rate) } \\
\hline If $t_{D}=0$, then $t_{Y}^{*}$ should be & 0.108 & 0.0373 \\
\hline If $t_{Y}=0$, then $t_{D}^{*}$ should be & 0.270 & 0.0933 \\
\hline If $t_{Y}=0.05$, then $t_{D}^{*}$ should be & 0.241 & - \\
\hline \multicolumn{3}{|l|}{ Effect on emissions $(D)$ (in percent) from } \\
\hline$\widehat{t_{Y}}$ & -0.0996 & -0.5000 \\
\hline$\hat{t_{D}}$ & -0.3379 & -0.8000 \\
\hline \multicolumn{3}{|c|}{ Effect on the polluting good ( $Y$ ) (in percent) from } \\
\hline$\widehat{t_{Y}}$ & -0.0996 & -0.5000 \\
\hline$\hat{t_{D}}$ & -0.0379 & -0.2000 \\
\hline \multicolumn{3}{|l|}{ Welfare effects (in percent) from } \\
\hline$\hat{t_{Y}}$ & 0.0037 & 0.0060 \\
\hline$\hat{t_{D}}$ & 0.0226 & 0.0096 \\
\hline
\end{tabular}


The simulation results confirm the theoretical prediction in that the effects on $D$ from introducing a small $t_{D}$ (i.e., one percent) are greater than those from $t_{Y}$. In particular, a marginal increase in $t_{D}$ reduces $D$ by 0.3379 percent for a developing country, which is more than three times larger than the size of the decrease in $D$ from $t_{Y}(0.0996$ percent $)$. For a developed country, the decrease in $D$ is greater than in a developing country. Especially, emissions decrease by 0.80 percent if a developed country introduces a small $t_{D}$

The effects on the polluting good $(Y)$ from a marginal increase of either $t_{Y}$ or $t_{D}$ are different from the effects on $D$. In particular, introduction of a small $t_{Y}$ decreases $Y$ by the exactly same magnitudes as it decreases $D$ in both developing and developed countries. However, the strength of $t_{D}$ in reducing $Y$ is much weaker. In developed country, the magnitudes of reduction in $Y$ from $t_{D}$ amount to only a quarter of the magnitudes of reduction in $D$, whereas the magnitudes of reduction in $Y$ from $t_{D}$ amount to only a tenth of the magnitudes of reduction in $D$ in developing country. This is because the change in relative input prices affects $D$ differently than $Y$ when $\sigma_{Y}$ is positive. With substitution in production, the firm can reduce $D$ more than $Y$ and change pollution per unit of output, by an extent that increases with $\sigma_{Y}$. Hence, for both developing and developed countries, the relative strength of $t_{D}$ (compared to $t_{Y}$ ) is smaller for reducing $D$ and $Y$.

The welfare gain from introducing a small $t_{D}$ is always greater than that from a small increase in $t_{Y}$. Recall that the major strength of an emissions tax is that it provides both output and substitution effects, while the output tax only provides an output effect. For the developed country case, the welfare gain from $\widehat{t_{D}}(0.0096)$ is about 50 percent larger than the gain from $\widehat{t_{Y}}(0.0060)$. For the developing country case, however, the relative strength of $\widehat{t_{D}}$ over $\widehat{t_{Y}}$ becomes larger (0.0226 percent), which is more than six times greater than the gain $(0.0037$ percent $)$ from $\widehat{t_{Y}}$. 
Another interesting point is that the welfare gain from $\widehat{t_{D}}(0.0226$ percent $)$ is larger for a developing country than for a developed country ( 0.0096 percent). This result is quite robust for the assumptions on some important parameters, as shown in the sensitivity analyses later.

One important policy implication from this result is that the potential welfare loss from not being able to use $t_{D}$ could be bigger in developing countries. The difference in the welfare gains between $\widehat{t_{Y}}$ and $\widehat{t_{D}}$ is 0.0189 percentage points $(=0.0226-0.0037)$ for the developing country case, while it is only 0.0036 percentage points $(=0.0096-0.0060)$ for the developed country case. The simulation results imply that the potential welfare loss from using $\widehat{t_{Y}}$ instead $\widehat{t_{D}}$ might be quite big especially in developing countries.

At this point, it would be interesting to ask how the assumptions on parameters between developed countries and developing countries affect the simulation results shown above. Table 3 shows the decomposition of the simulation results by parameter assumption. The first two columns show the base cases for developed as well as developing countries already shown in Table 2 . The remaining columns show how the 'developing countries case' results would change as each single parameter value for the developing countries changes to that for the developed countries.

The most striking point of Table 3 is that any change in a single parameter value for the case of developing countries can bring not so much reduction in emissions and the polluting good consumption by using either $t_{Y}$ or $t_{D}$. All the numbers in the first four rows show that the reduction rates in $D$ as well as $Y$ from the uses of $t_{D}$ and $t_{Y}$ in the case for developing countries are about a half (and in many cases, one third) of those in the case for developed countries. These results strengthens the implications drawn from the numerical simulation results in that any tax policies for the purpose of environmental improvement might be limited in their scopes and effects in developing countries without the simultaneous changes in other structural factors. 
First, consider the third column that reports how the base simulation results for developing countries change if labor tax rate increases to the level assumed for developed countries $\left(t_{L}=0.40\right)$ from that for developing countries $\left(t_{L}=0.25\right)$ with other parameter values fixed at the base case for developing countries. Usages of environmental taxes with much higher pre-existing labor tax result in much larger distortion in terms of social marginal cost of public funds. Therefore, introducing $t_{Y}$ or raising its rate do not help developing country decrease $D$ and $Y(+0.0081)$. With higher distortionary labor income tax at 40 percent, the developing country can use $t_{D}$ to effectively reduce $D$. Note that the numbers reported in the third column are smaller than those in the second column (the base case for developing countries) in absolute value. It means that higher labor income tax rate makes disposable income smaller and causes larger labor supply distortion, generating less effective results in both reducing emissions and the polluting good consumption and improving welfare.

The fourth column $\left(t_{Y}=0\right)$, the case that consumption tax rate is changed to zero, shows that the opposite results happen compared to the case of raising labor income tax rate. With no consumption tax, developing countries can have slightly stronger effects in reducing emissions and the polluting good consumption and in improving welfare by introducing (or raising) either consumption tax or emissions tax. It is because marginal positive change in consumption tax rate considerably decreases the polluting good consumption (-0.1133), which is slightly bigger than the base case result $(-0.0996)$. Therefore, the size of welfare improvement from the use of consumption tax becomes bigger in this case $(0.0079)$ than the base case $(0.0037)$. 
〈Table 3〉 The decomposition of the simulation result by parameter assumption (in percent)

\begin{tabular}{|c|c|c|c|c|c|c|c|c|c|}
\hline & $\begin{array}{c}\text { Developed } \\
\text { Countries } \\
\text { (e.g., the } \\
\text { U.S.) }\end{array}$ & $\begin{array}{c}\text { Developing } \\
\text { Countries } \\
\text { (e.g., } \\
\text { China) }\end{array}$ & $t_{L}=0.4$ & $t_{Y}=0$ & $\mu=0.1$ & $\epsilon=0.1$ & $\sigma_{Y}=1$ & $\sigma_{Q}=1$ & $\frac{Y}{L}=0.3$ \\
\hline \multicolumn{10}{|c|}{$\begin{array}{l}\text { Effect on } \\
\text { emissions } \\
(D) \text { from }\end{array}$} \\
\hline$\hat{t_{Y}}$ & -0.5000 & -0.0996 & 0.0081 & -0.1133 & -0.0996 & -0.0983 & -0.0996 & -0.1991 & -0.2986 \\
\hline$\hat{t_{D}}$ & -0.8000 & -0.3379 & -0.2969 & -0.3453 & -0.3379 & -0.3375 & -0.6379 & -0.3759 & -0.4138 \\
\hline \multicolumn{10}{|c|}{$\begin{array}{l}\text { Effect on the } \\
\text { polluting } \\
\text { good } \\
\text { production } \\
(Y) \text { from }\end{array}$} \\
\hline$t_{Y}$ & -0.5000 & -0.0996 & 0.0081 & -0.1133 & -0.0096 & -0.0983 & -0.0996 & -0.1991 & -0.2986 \\
\hline$\hat{t_{D}}$ & -0.2000 & -0.0379 & 0.0031 & -0.0453 & -0.0379 & -0.0375 & -0.0379 & -0.0759 & -0.1138 \\
\hline \multicolumn{10}{|l|}{$\begin{array}{l}\text { Welfare } \\
\text { effects of }\end{array}$} \\
\hline$\hat{t_{Y}}$ & 0.0060 & 0.0037 & -0.0003 & 0.0079 & -0.0009 & 0.0039 & 0.0037 & 0.0074 & 0.0058 \\
\hline$\widehat{t_{D}}$ & 0.0096 & 0.0226 & 0.0212 & 0.0240 & 0.0067 & 0.0225 & -0.0437 & 0.0240 & 0.0131 \\
\hline
\end{tabular}

It also slightly increases the size of welfare improvement (from 0.0226 to 0.0240 ) from the introduction of emissions tax.

The fifth column, which is the case that the MEDs become smaller $(\mu=1)$, shows that the effects of $t_{Y}$ as well as $t_{D}$ on $D$ and $Y$ do not change from the base case for developing countries. With low level of MEDs and non-zero consumption tax rate (i.e., $\mu=0.1$ and $t_{Y}=0.05$ ), additional increase of tax rates or introduction of new tax exacerbates the distortions in the economy, whereas the additional effects from environmental improvement from higher tax rates are negligible. Therefore, the welfare effects from the use of $t_{Y}$ becomes negative (-0.0009). In the case of $t_{D}$, welfare increases only marginally $(0.0067)$. 
In the case of lower elasticity of market labor supply $(\epsilon=0.1)$, which is reported at the sixth column, the effects on pollution reduction and welfare improvement more or less the same with the base case for developing countries.

Both the seventh and eighth columns show how the base case simulation results change if the substitution elasticity between dirty and clean inputs $\left(\sigma_{Y}=1\right)$ as well as the one between polluting and clean goods $\left(\sigma_{Q}=1\right)$ become larger. Note that the higher input substitutability for the polluting good $\left(\sigma_{Y}\right)$ combined with the use of $t_{D}$ can greatly reduce emissions (-0.6379), which is twice greater than the reduction rate for base case $(-0.3379)$. On the other hand, the higher consumption goods substitutability $\left(\sigma_{Q}\right)$ combined with the use of $t_{Y}$ can greatly reduce $D$ and $Y$. The changes in welfare follow the same pattern: higher $\sigma_{Y}$ with $t_{D}$ improves welfare twice greater than the base case, while higher $\sigma_{Q}$ with $t_{Y}$ shows twice bigger welfare change than the base case.

The last (ninth) column in Table 3 shows how the simulation results change when the ratio of the polluting industries to GDP $(Y / L=0.3)$ becomes lower. If $Y / L$ becomes lower in developing countries, the change in emissions from the use of $t_{Y}$ decreases further (from -0.0996 to -0.2986 ). Other things being equal, smaller portion of dirty good industries in GDP increases the relative strength of tax instruments in reducing pollution. Since $t_{Y}$ directly affects the consumption of $Y$ by increasing the consumer price of the polluting consumption good, the size of pollution reduction in $D$ and $Y$ becomes more effective when combined with the use of $t_{Y}$.

\section{Sensitivity Analysis}

Some parameter values used in the numerical simulation are uncertain due to measurement problem. Hence, I use some alternative values for the substitution elasticities $\left(\sigma_{Q}\right.$ and $\left.\sigma_{Y}\right)$ and the elasticity of market labor supply $(\epsilon)$. Figures 1 3 below show how the size of the welfare gains depends on the assumptions on these parameter values. 
For $\sigma_{Q}$, the welfare gain from either $\widehat{t_{Y}}$ or $\widehat{t_{D}}$ increases for both developing and developed countries as the substitution ability between outputs increases. However, the gap becomes smaller as $\sigma_{Q}$ increases. For example, the welfare gains from $\widehat{t_{Y}}$ and $\widehat{t_{D}}$ are same with each other when $\sigma_{Q}=2.0$ for developed countries $<$ see Figure 1>. This suggests that the welfare effects from the use of the environmental output taxes could be close to the welfare gain from an ideal Pigouvian tax if the substitution in consumption is large enough. For the welfare gain from $\widehat{t_{Y}}$ and $\widehat{t_{D}}$ to be same with each other for developing countries, the substitution in consumption should be very large. This suggests that, if the substitutability between consumption goods is not large in developing countries, the potential welfare loss from not being able to use an ideal Pigouvian tax (and using consumption tax instead) would be larger than developed countries.

The welfare gain also increases as $\sigma_{Y}$ gets higher $<$ see Figure 2>. Moreover, the relative strength of $\widehat{t_{D}}$ over $\widehat{t_{Y}}$ becomes larger as $\sigma_{Y}$ increases. For the extreme case, if $\sigma_{Y}$ is very small, then the welfare gain from the use of $\widehat{t_{D}}$ could be smaller than the welfare gain from $\widehat{t_{Y}}$. However, the result that developing countries have larger potential welfare loss from not being able to use $t_{D}$ are still valid (and even strengthened) as $\sigma_{Y}$ increases.

The size of $\epsilon$ has no effects on welfare for the developed country $<$ see Figure $3>$. However, this is because the developed country has no pre-existing $t_{Y}$ or $t_{D}$. In this case, the effects from the changes in $\epsilon$ are incidentally cancelled out from both numerator and denominator in welfare expression. If $t_{Y}$ is non-zero, then the welfare effects follow more or less the same pattern as in the developing country. For developing country, the size of $\epsilon$ has generates negligible changes in welfare. 
〈Figure 1〉 Sensitivity analysis for substitution elasticities between outputs $\left(\sigma_{Q}\right)$
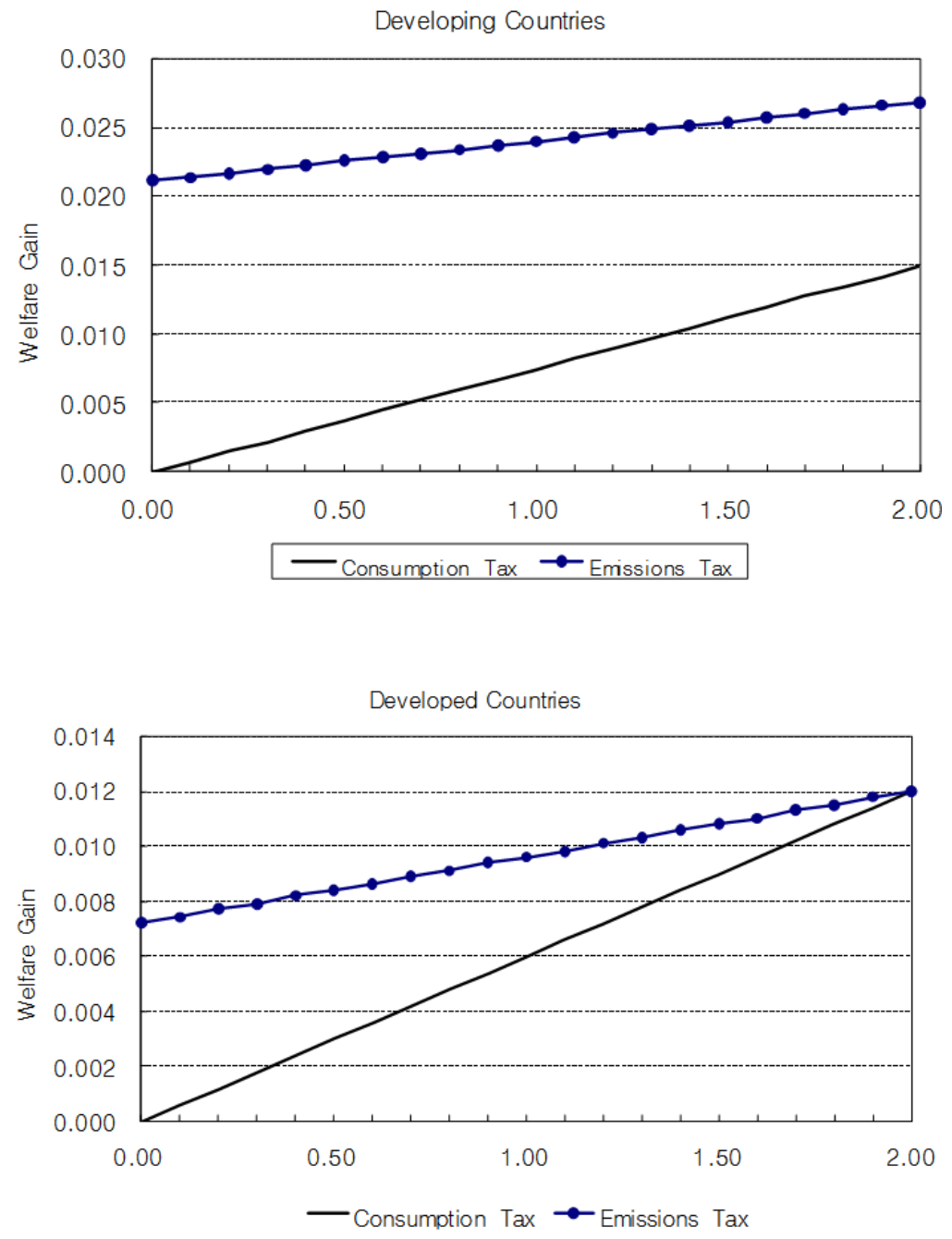
Potential Welfare Loss from Using Imperfect Environmental Taxes

〈Figure 2〉 Sensitivity analysis for substitution elasticities between inputs $\left(\sigma_{Y}\right)$
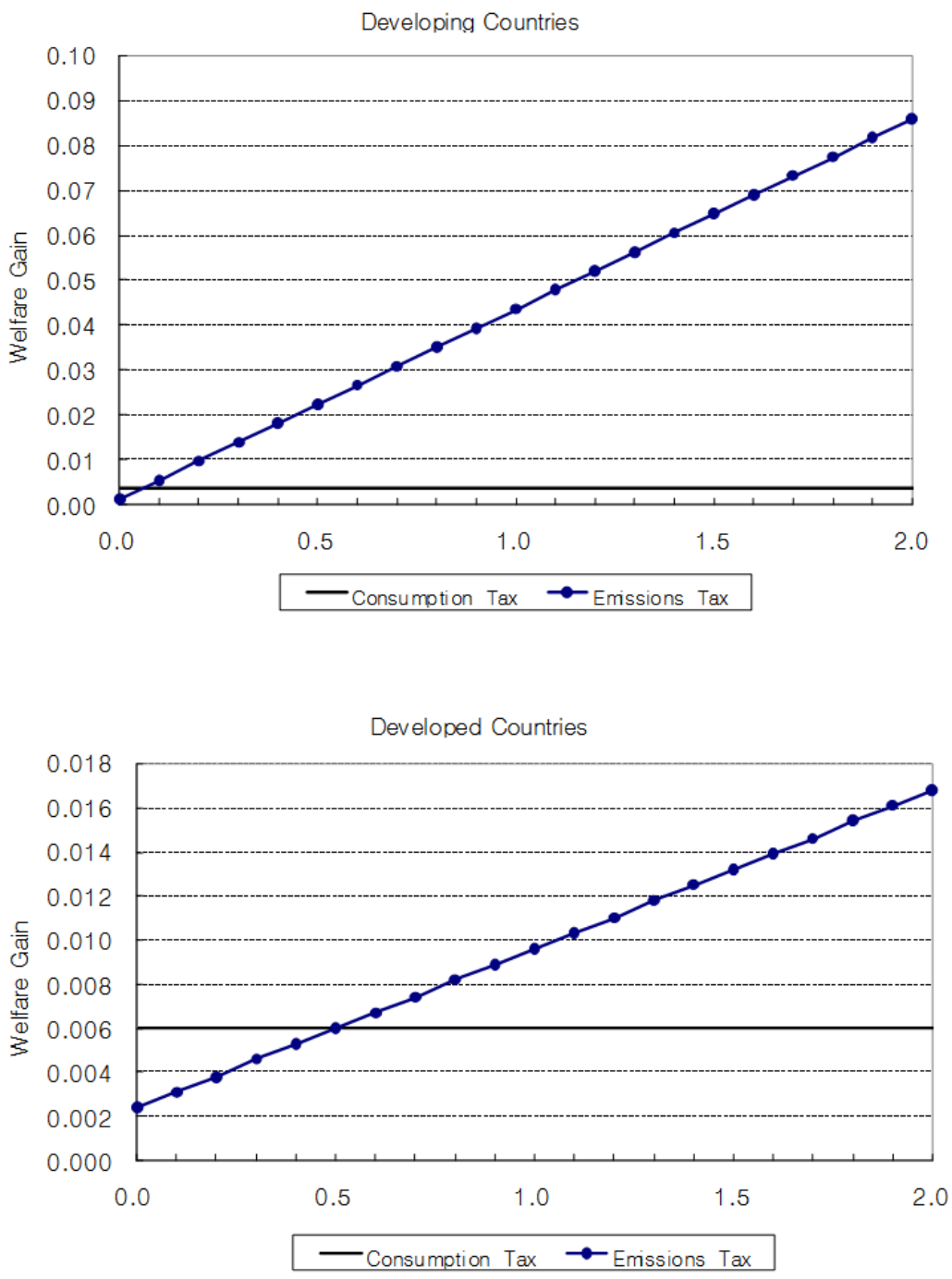
〈Figure 3〉 Sensitivity analysis for labor supply elasticities $(\epsilon)$
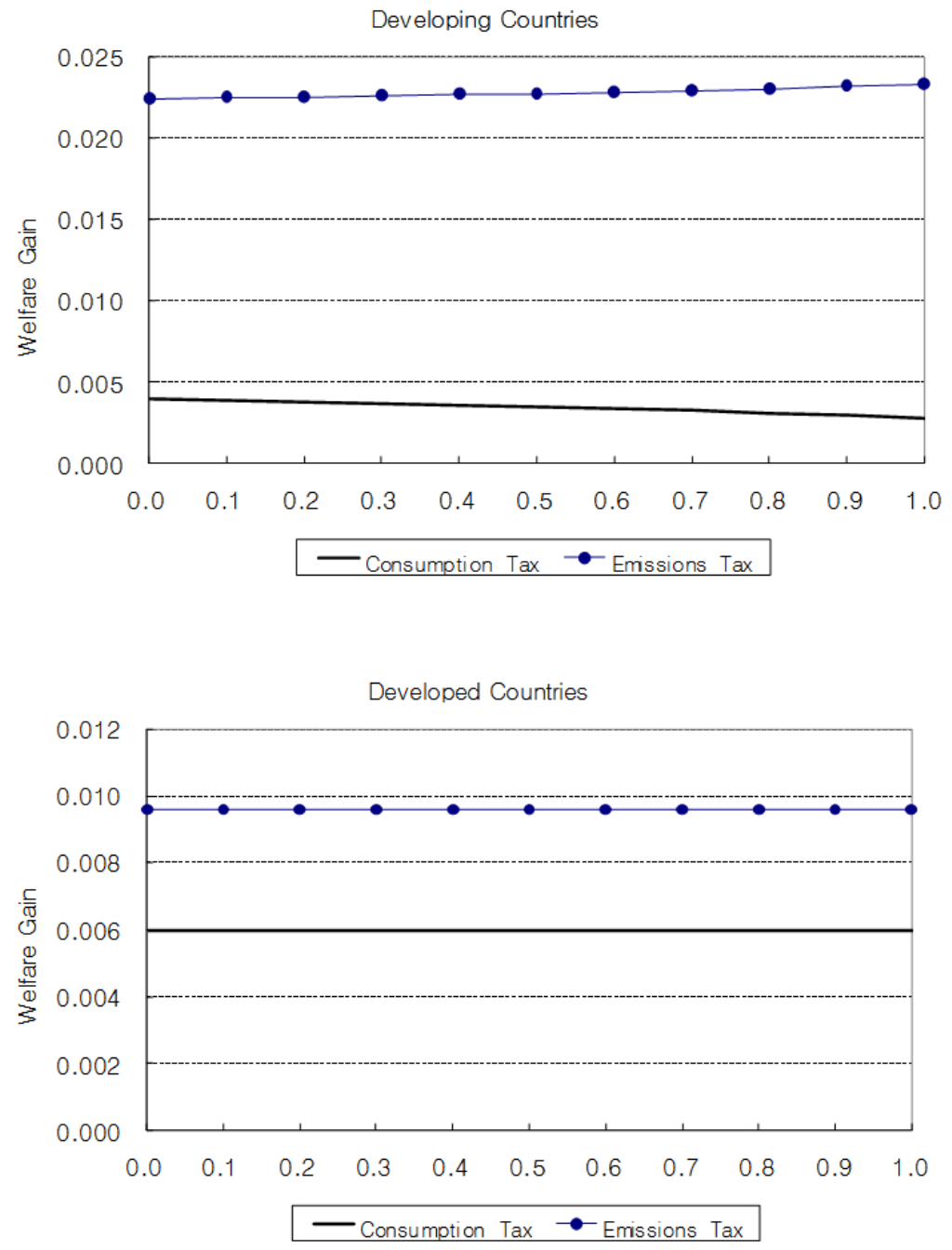

\section{Concluding Remarks}

In this paper, I use a simple general equilibrium model to examine how structural and institutional constraints might affect the relative performances of an ideal Pigouvian tax 
and an environmental output tax in developing countries. Although a Pigouvian tax has been shown theoretically to correct numerous environmental problems, many surveys reveal that most actual environmental taxes being used in many countries are applied to the output of a polluting industry (or to an input that is correlated with emissions).

This paper shows theoretically that a Pigouvian tax is superior to an output tax in welfare terms, because it provides the substitution effect among inputs as well as the output effect. However, the introduction of an ideal Pigouvian tax is usually not practical, due to administrative and informational problems. These problems are much more severe in developing countries. Furthermore, many developing countries suffer from other structural constraints such as high marginal environmental damages, large traditional (and often non-taxable) sectors, a larger proportion of polluting industries in total output, and many out-dated and polluting production technologies. Due to these additional constraints, developing countries might experience larger potential welfare disadvantages from not being able to use Pigouvian taxes.

With a set of parameter values from China, which is believed to have many structural characteristics in common with developing countries, this paper shows that the net welfare gain from the use of a Pigouvian tax could be six times larger than that of an output tax. Moreover, the potential welfare disadvantage from not being able to use an ideal Pigouvian tax is greater in developing countries than in developed countries. This result suggests that development of policy instruments that are more accurately connected to polluting behavior is more urgent in developing countries. Furthermore, this potential welfare disadvantage implies that developing countries' efforts in various structural reforms have important effects on the welfare outcomes of their environmental policies. Moreover, this welfare disadvantage does not imply that developing countries should avoid using environmental tax instruments. Although an introduction of an environmental output tax offers a smaller welfare gain in developing countries than in developed countries, the welfare gain from output tax instruments might be substantial, considering the potential savings from monitoring and enforcement activities. 
My results here concern welfare cost of being not able to use emissions (Pigouvian) taxes. My model evaluates the output tax as a policy that can be implemented more easily than emissions tax. For actual environmental policy, however, governments might choose CAC policy instruments rather than output tax. When ideal tax is not available, countries use other $\mathrm{CAC}$ rules or non-market policies. And this tendency might be stronger in developing countries. Some forms of mandate such as a quantity restriction on pollution or certain equipment requirement might be chosen instead of emissions tax. My model in this paper does not explicitly consider this point. Under competitive conditions, market-based instruments usually perform better than CAC. In the presence of market imperfections, however, the effectiveness of the different policy instruments is ambiguous (Raquate, 2005). As shown by Fullerton and Metcalf(2001), the effectiveness of welfare improving environmental policy instruments comes not from its revenueraising property: any policy instruments that generate privately-retained scarcity rents exacerbate the pre-existing labor tax distortion. In this sense, my model can be further modified to consider what structural and institutional characteristics in developing countries are important in generating privately-held scarcity rents. In one hand, many developing countries suffer from not too transparent law-making as well as enforcement problems. For example, corruption tends to increase scarcity rents. On the other hand, any organized objections to delay adoption of market-based environmental policy instruments and to maintain scarcity rents might be weaker in developing countries. Formalization of these points into my model following Fullerton and Metcalf (2001) would be one of several possible extensions of my paper.

Other research questions not examined in this paper represent important directions for further study. First, this paper considers a tax on output of the polluting (and taxable) industry, for comparison with ideal Pigouvian taxes. However, some of the actual environmental taxes apply to inputs to production that are correlated with emissions. To analyze such taxes, my model could be modified such that the polluting industry uses three inputs to production: labor, emissions, and some other inputs that are correlated 
with emissions.

I also note that this paper relies on many other standard simplifying assumptions such as a closed economy with perfect certainty and perfect competition, homogeneity among firms and households, and no trans-boundary pollution. Even though a closed economy model is an adequate representation of China, many developing countries are smaller and more open than China. On the other hand, one might vary the assumption of perfect competition, because the state and collectives own many enterprises in Chinese industry, even though their importance has been reduced. 


\section{[Appendix A] Derivation of (19)}

From the zero-profits condition,

$$
p_{Y} F\left(L_{Y}, D\right)=L_{Y}+\left(1+t_{D}\right) D
$$

Totally differentiating it to obtain the first-order conditions:

$$
F\left(L_{Y}, D\right) d p_{Y}+p_{Y}\left(F_{L_{Y}} d L_{Y}+F_{D} d D\right)=d L_{Y}+\left(1+t_{D}\right) d D+D d t_{D}
$$

Plugging the first-order conditions from the profit maximization into it:

$$
Y d p_{Y}=D d t_{D}
$$

Dividing the both sides of (A2) by $p_{Y}$ gives (19) in the main text.

\section{[Appendix B] Solving the system of equations}

From (22) and (23), the change in labor can be derived as follows:

$$
\hat{L}=\left(\frac{\epsilon}{1-t_{L}-\epsilon t_{L}}\right)\left[t_{Y}\left(\frac{Y}{L}\right) \hat{Y}+t_{D}\left(\frac{D}{L}\right) \hat{D}\right]
$$

Defining the elasticity of substitution between two manufactured goods $\left(\sigma_{Q}\right)$ as $d(X / Y) /(X / Y)$ divided by $d\left(c_{Y} / p_{X}\right) /\left(c_{Y} / p_{X}\right)$, a behavioral equation can be obtained as follows:

$$
\widehat{Y}=\hat{X}-\sigma_{Q} \widehat{c_{Y}}
$$

Totally differentiate the household's budget constraint and use (19), (21), and (B2) to get: 


$$
\hat{X}=\hat{L}+\hat{w}+\phi \sigma_{Q} \hat{c_{Y}}
$$

where $\phi \equiv\left(1+t_{Y}\right) Y /\left(1-t_{L}\right) L$, which is the ratio of the consumer expenditure to a polluting manufactured good to the after-tax income from market labor.

Plug (B3) into (B2), then:

$$
\hat{Y}=\hat{L}+\hat{w}-\sigma_{Q}(1-\phi) \widehat{c_{Y}} \text {. }
$$

Defining the elasticity of substitution between inputs in production of $Y$ (i.e., $\sigma_{Y}$ ) as $d\left(L_{Y} / D\right) /\left(L_{Y} / D\right)$ divided by $d\left(1+t_{D}\right) /\left(1+t_{D}\right)$, a behavioral equation can be obtained as follows:

$$
\widehat{L_{Y}}=\widehat{D}+\sigma_{Y} \widehat{t_{D}}
$$

The first-order conditions from the profit maximization imply that $d Y=d L_{Y}+$ $\left(1+t_{D}\right) d D$. Thus, the percentage change in $Y$ can be expressed as a weighted average of the percentage changes in the two inputs:

$$
\hat{Y}=\left(\frac{L_{Y}}{Y}\right) \widehat{L_{Y}}+\left(1+t_{D}\right)\left(\frac{D}{Y}\right) \hat{D} .
$$

Substitute (B5) into (B6) and use the zero-profits condition $Y=L_{Y}+\left(1+t_{D}\right) D$ at the initial equilibrium where all prices are one to get:

$$
\hat{Y}=\hat{D}+\sigma_{Y}\left(\frac{L_{Y}}{Y}\right) \widehat{t_{D}}
$$

The definition of the consumer price of $Y$ is given $c_{Y}=p_{Y}+t_{Y}$. Totally differentiating it,

$$
\frac{d c_{Y}}{c_{Y}}=\left(\frac{p_{Y}}{p_{Y}+t_{Y}}\right)\left(\frac{d p_{Y}}{p_{Y}}\right)+\frac{d t_{Y}}{p_{Y}+t_{Y}} .
$$


Since $p_{Y}=1$ (but $d p_{Y} \neq 0$ ) by assumption,

$$
\widehat{c_{Y}}=\frac{1}{\left(1+t_{Y}\right)} \widehat{p_{Y}}+\widehat{t_{Y}}
$$

Substituting (19) into (B8):

$$
\widehat{c_{Y}}=\widehat{t_{Y}}+\left(\frac{1+t_{D}}{1+t_{Y}}\right) \widehat{t_{D}} .
$$

Now, the equations (14), (15), (21), (23), (B2), (B3), (B5), (B6), and (B9) are a system of simultaneous equations that can be solved for the nine endogenous variables $\left(d U / \lambda L, \widehat{t_{L}}, \hat{X}, \hat{Y}, \hat{D}, \hat{w}, \hat{L}, \widehat{L_{Y}}\right.$, and $\left.\widehat{c_{Y}}\right)$ as functions of exogenous parameters and two exogenous policy variables, $\widehat{t_{Y}}$ and $\widehat{t_{D}}$. Then, for any particular policy experiment, one of these two tax rate changes will be set to zero in order to look at the effects of the other, where the change in revenue is offset by an adjustment in the labor $\operatorname{tax} t_{L}$.

In order to solve the nine equations, they need to be reduced to fewer equations. To get the expression for the change in emissions $(\hat{D})$, substitute (22) into (B4) and use (B1), and then:

$$
\hat{Y}=\left\{\frac{(1+\epsilon) t_{D}\left(\frac{D}{L}\right)}{1-(1+\epsilon)\left[t_{L}+t_{Y}\left(\frac{Y}{L}\right)\right]}\right\} \hat{D}-\left\{\frac{\sigma_{Q}(1-\phi)\left[1-(1+\epsilon) t_{L}\right]}{1-(1+\epsilon)\left[t_{L}+t_{Y}\left(\frac{Y}{L}\right)\right]} \hat{c_{Y}} \cdot\right. \text { (B10) }
$$

Equate (B10) with (B7) and use (B9) to get $\widehat{D}$ in (24). For $\hat{Y}$ in (25), substitute (24) into (B7). Finally, for $\hat{L}$ in (26), substitute (24) and (25) into (B1). 


\section{[References]}

1. Barthold, T. A., "Issues in the Design of Environmental Excise Taxes," Journal of Economic Perspectives, Vol. 8, 1994, pp. 133 51 .

2. Baumol, W. J., and W. E. Oates, The Theory of Environmental Policy: Second Edition, New York: Cambridge University Press, 1988.

3. Bell, R. G., and C. Russell, "Environmental Policy for Developing Countries." Issue in Science and Technology, Spring, 2002, pp. 63 70 .

4. Blackman, A., "Alternative Pollution Control Policies in Developing Countries," Review of Environmental Economics and Policy, Vol. 8, No. 2, 2010, pp. 234 253. 5. , and W. Harrington, "The Use of Economic Incentives in Developing Countries:

Lessons from International Experience with Industrial Air Pollution,” Journal of Environment and Development, Vol. 9, 2000, pp. 5 45.

6. Bovenberg, A. L., and R. A. de Mooij, "Environmental Levies and Distortionary Taxation," American Economic Review, Vol. 84, 1994, pp. 1085 1089.

7. Cremer, H., and F. Gahvari, "Second-best Taxation of Emissions and Polluting Goods," Journal of Public Economics, Vol. 80, 2001, pp. 169 197.

8. Cropper, M., and W. Oates, "Environmental Economics: A Survey," Journal of Economic Literature, Vol. 30, 1992, pp. 675 740 .

9. Earnhart, D., "The Effects of Community Characteristics on Polluter Compliance Levels," Land Economics, Vol. 80, 2004, pp. 408 432.

10. Economy, E. C., The River Runs Black: The Environmental Challenge to China's Future. Ithaca, NY: Cornell University Press, 2004.

11. Eskeland, G., Taxing Bads by Taxing Goods, Washington, D.C.: World Bank, 1995. 12 . , and E. Jimenez, "Policy Instruments for Pollution Control in Developing Countries," World Bank Research Observer, Vol. 7, 1992, pp. 145 169 .

13. , E. Jimenez, and L. Liu, "Prices that Clear the Air: Energy Use and Pollution

in Chile and Indonesia," Energy Journal, Vol. 19, 1998, pp. 85 106.

14. Freeman, A. M., Air and Water Pollution Control: A Benefit-Cost Assessment, New York: John Wiley and Sons. 1982. 
15. Fullerton, D., and G. E. Metcalf, "Environmental Controls, Scarcity Rents, and Pre-Existing Distortions," Journal of Public Economics, Vol. 80, 2001, pp. 249 267. 16. , I. Hong, and G. E. Metcalf, "A Tax on Output of the Polluting Industry is not a Tax on Pollution: The Importance of Hitting the Target.” in C. Carraro and G. Metcalf, eds., Distributional and Behavioral Effects of Environmental Policy, Chicago: University of Chicago Press, 2001.

17. Goulder, L., and R. C. Williams III, "The Substantial Bias from Ignoring General Equilibrium Effects in Estimating Excess Burden, and a Practical Solution.” Journal of Political Economy Vol. 111, 2003, pp. 898 927.

18. Heritage Foundation, The 2000 Index of Economic Freedom, Washington, D.C., 2000.

19. Hoel, M., "Emission Taxes versus Other Environmental Policies." Scandinavian Journal of Economics, Vol.100, 1998, pp. 79 104 .

20. Jacoby, H. G., "Shadow Wages and Peasant Family Labour Supply: An Econometric Application to the Peruvian Sierra." Review of Economic Studies Vol. 60, 1993, pp. $903 \sim 921$.

21. Jha, R., and J. Whalley, "The Environmental Regime in Developing Countries." In C. Carraro and G. Metcalf, eds., Distributional and Behavioral Effects of Environmental Policy. Chicago: University of Chicago Press for NBER, 2001.

22. López, R, "Structural Adjustment and Sustainable Development," in Ramón López and Michael A. Toman, eds., Economic Developments and Environmental Sustainability: New Policy Options, Oxford University Press, 2006, pp. 154 177.

23. McMorran, R. T., and D. C. L. Nellor, "Tax Policy and the Environment: Theory and Practice." IMF Working Paper 94 106, Washington, DC: International Monetary Fund, 1994.

24. National Bureau of Statistics of China, China Statistics Yearbook 2013. People's Republic of China. http://www.stats.gov.cn/tjsj/ndsj/2013/indexeh.htm. Accessed December 3, 2014.

25. O’Connor, D., “Applying Economic Instruments in Developing Countries: from Theory to Implementation.” Environment and Development Economics, Vol. 4, 1998, pp. 91 110 .

26. Organization for Economic Cooperation and Development (OECD), Economic Instruments for Environmental Protection. Paris: OECD, 1989. 
27. Applying Economic Instruments to Environmental Policies in OECD and Dynamic Non-Member Economies. Paris: OECD, 1994.

28. , Environmental Taxes in OECD Countries, Paris: OECD, 1995.

29. , Environmental Performance in OECD Countries: Progress in the 1990s. Paris: OECD, 1996.

30. , Consumption Tax Trends. Paris: OECD, 1999.

31. , "Economic Instruments for Pollution Control and Natural Resources Management in OECD Countries: A Survey." OECD Working Papers 72, Paris: OECD, 1999. 32. , Environmentally Related Taxes in OECD Countries: Issues and Strategies. Paris: OECD, 2001.

33. , The Political Economy of Environmentally Related Taxes. Paris: OECD, 2006.

34. , Green Growth and Developing Countries: A Summary for Policy maekrs. Paris: OECD, 2012.

35. Panayotou, T., "Economic Incentives in Environmental Management and Their Relevance to Developing Countries." In Denizhan Erôcal ed., Environmental Management in Developing Countries. Paris: OECD, 1991.

36. Pearce, D. W., and R. K. Turner, Economics of Natural Resources and the Environment. Baltimore: Johns Hopkins University Press, 1990.

37. Pigou, A. C., The Economics of Welfare (Fourth Edition). London: MacMillan, 1932.

38. Rosenzweig, M.R., "Neoclassical Theory and the Optimizing Peasant: An Econometric Analysis of Market Family Labor Supply in a Developing Country." Econometrica, Vol. 94, 1980, pp. 31 55.

39. Russell, C. S., and P. T. Powell, "Choosing Environmental Policy Tools: Theoretical Cautions and Practical Considerations.” Washington, D.C.: Inter-American Development Bank, 1996.

40. Sandmo, A., "Optimal Taxation in the Presence of Externalities." Swedish Journal of Economics, Vol. 77, 1975, pp. 86 98.

41. Schmutzler, A., and L. H. Goulder, "The Choice between Emission Taxes and Output Taxes under Imperfect Monitoring.” Journal of Environmental Economics and Management, Vol. 32, 1997, pp. 51 64 . 
42. Schneider, F., and D. Enste, "Shadow Economies around the World: Size, Causes, and Consequences.” Journal of Economic Literature, Vol. 38, 2000, pp. 77 114 .

43. Serôa da Motta, R., R. M. Huber, and H. J. Ruitenbeek, "Market Based Instruments for Environmental Policymaking in Latin ATmerica and the Caribbean: Lessons from Eleven Countries.” Environment and Development Economics, Vol. 4, 1999, pp. 177 201.

44. Smith, S., "Taxation and the Environment." In Michael P. Devereux ed., The Economics of Tax Policy. London: Oxford University Press, 1996.

45. __ Evaluating Economic Instruments for Environmental Policy. Paris: OECD, 1997.

46. Smulders, S., and H. R. J. Vollebergh, "Green Taxes and Administrative Costs: The Case of Carbon Taxation.” In C. Carraro and G. Metcalf, eds., Distributional and Behavioral Effects of Environmental Policy. Chicago: University of Chicago Press, 2001.

47. Somanathan, E., "Effects of Information on Environmental Quality in Developing Countries," Review of Environmental Economics and Policy, Vol. 4, No. 2, 2010, pp. $275 \sim 292$.

48. Speck, S., and D. Gee, "Implications of Environmental Tax Reforms: Revisited." In L. Kreiser, J. Sirisom, H. Ashiabor, J. Milne eds., Environmental Taxation and Climate Change: Achieving Environmental Sustainability Through Fiscal Policy, Northampton, MA: Edward Elgar, 2001.

49. State Administration of Taxation of the People's Republic of China (SAT-PRC), “China’s Tax System.” http://www.chinatax.gov.cn/2013/n2925/n2959/c307248/content.html. Accessed Dec. 3, 2014.

50. Stavins, R. N., "Experience with Market-Based Environmental Policy Instruments." In K.-G. Maler and J.R. Vincent, eds., Handbook of Environmental Economics, Volume 1, Amsterdam, The Netherlands: Elsevier, 2003, pp. 355 421.

51. Tanzi, V., and H. H. Zee, "Tax Policy for Emerging Markets: Developing Countries." National Tax Journal, Vol. 53, 2000, pp. 299 322.

52. Varma, A., "The Economics of Slash and Burn: A Case Study of the 1997-1998 Indonesian Forest Fires.” Ecological Economics, Vol. 46, 2003, pp. 159 171.

53. Vatn, A., "Input versus Emission Taxes: Environmental Taxes in a Mass Balance and 
Transaction Costs Perspective.” Land Economics, Vol. 74, No. 4, 1998, pp. 514 25 .

54. World Bank, Clear Water, Blue Skies: China's Environment in the New Century. Washington, D. C.: World Bank, 1997.

55. __ Cost of Pollution in China: Economic Estimates of Physical Damages. Washington, DC: World Bank, 2007.

56. Yang, J., D. Cao, and D. Wang, "The Air Pollution Charge System in China," in OECD, Applying Market-Based Instruments to Environmental Policies in China and OECD Countries, Paris: OECD, 1997. 